\title{
tert-Butylcarbamate-Containing Histone Deacetylase Inhibitors: Apoptosis Induction, Cytodifferentiation, and Antiproliferative Activities in Cancer Cells
}

\author{
Sergio Valente, ${ }^{[\mathrm{a}]}$ Daniela Trisciuoglio, ${ }^{[\mathrm{b}]}$ Maria Tardugno, ${ }^{[\mathrm{a}]}$ Rosaria Benedetti, ${ }^{[\mathrm{cc}}$ \\ Donatella Labella, ${ }^{[\mathrm{a}]}$ Daniela Secci, ${ }^{[\mathrm{a}]}$ Ciro Mercurio ${ }^{[\mathrm{d}]}$ Roberto Boggio, ${ }^{[\mathrm{e}, \mathrm{f]}}$ Stefano Tomassi, ${ }^{[\mathrm{g}]}$ \\ Salvatore Di Maro, ${ }^{[\mathrm{g}]}$ Ettore Novellino, ${ }^{[\mathrm{g}]}$ Lucia Altucci, ${ }^{*[\mathrm{c}, \mathrm{h}]}$ Donatella Del Bufalo, ${ }^{*[\mathrm{~b}]}$ \\ Antonello Mai, ${ }^{*[a]}$ and Sandro Cosconati*i]
} Herein we report novel pyrrole- and benzene-based hydroxa-
mates $(\mathbf{8}, \mathbf{1 0})$ and 2 -aminoanilides $(9,11)$ bearing the tert-bu-
tylcarbamate group at the CAP moiety as histone deacetylase
(HDAC) inhibitors. Compounds $\mathbf{8} \mathbf{b}$ and $10 \mathrm{c}$ selectively inhibit-
ed HDAC6 at the nanomolar level, whereas the other hydroxa-
mates effected an increase in acetyl- $\alpha$-tubulin levels in human
acute myeloid leukemia U 937 cells. In the same cell line, com-
pounds 8 b and $10 \mathrm{c}$ elicited 18.4 and $21.4 \%$ apoptosis, respec-
tively (SAHA: $16.9 \%)$, and the pyrrole anilide $9 \mathrm{c}$ displayed the highest cytodifferentiating effect $(90.9 \%)$. In tests against a wide range of various cancer cell lines to determine its antiproliferative effects, compound $10 \mathrm{c}$ exhibited growth inhibition from sub-micromolar (neuroblastoma LAN-5 and SH-SY5Y cells, chronic myeloid leukemia K562 cells) to low-micromolar (lung H1299 and A549, colon HCT116 and HT29 cancer cells) concentrations. In HT29 cells, 10 c increased histone H3 acetylation, and decreased the colony-forming potential of the cancer cells by up to $60 \%$.

\section{Introduction}

[a] Dr. S. Valente, Dr. M. Tardugno, ${ }^{+}$Dr. D. Labella, Prof. D. Secci, Prof. A. Mai Istituto Pasteur-Fondazione Cenci Bolognetti

Dipartimento di Chimica e Tecnologie del Farmaco

"Sapienza" Università di Roma, P.le A. Moro 5, 00185 Roma (Italy)

E-mail: antonello.mai@uniroma1.it

[b] Dr. D. Trisciuoglio, ${ }^{+}$Dr. D. Del Bufalo

Regina Elena National Cancer Institute

Laboratorio di Chemioterapia Sperimentale Preclinica

Via delle Messi d'Oro 156, 00158 Roma (Italy)

E-mail: delbufalo@ifo.it

[c] Dr. R. Benedetti, Prof. L. Altucci

Dipartimento di Patologia Generale

Seconda Università degli Studi di Napoli

vico L. De Crecchio 7, 80138 Napoli (Italy)

E-mail: lucia.altucci@unina2.it

[d] Dr. C. Mercurio

Genextra Group, DAC s.r.l., Via Adamello 16, 20139 Milano (Italy)

[e] Dr. R. Boggio

Genextra Group, Congenia s.r.l., Via Adamello 16, 20139 Milano (Italy)

[f] Dr. R. Boggio

Present address: Nerviano Medical Sciences

Via Pasteur 10, 20014 Nerviano (Italy)

[g] Dr. S. Tomassi, Dr. S. Di Maro, Prof. E. Novellino

Dipartimento di Chimica Farmaceutica e Tossicologica

Università degli Studi di Napoli "Federico II"

Via D. Montesano 49, 80131 Napoli (Italy)

[h] Prof. L. Altucci

IGB-CNR, Via P. Castellino Napoli (Italy)

[i] Dr. S. Cosconati

DiSTABiF, Seconda Università di Napoli

Via G. Vivaldi 43, 81100 Caserta (Italy)

E-mail: sandro.cosconati@unina2.it

$\left.{ }^{[}\right]$These authors contributed equally to this work.

Supporting information for this article is available on the WWW under http://dx.doi.org/10.1002/cmdc.201300005.
The acetylation and deacetylation of histones have emerged as critical components of an epigenetic indexing system, demarcating transcriptionally active chromatin domains or gene silencing. This dynamic balance is regulated by two families of enzymes: histone acetyltransferases (HATs) and histone deacetylases (HDACs). ${ }^{[1]}$ Acetylation of lysine residues, catalyzed by HATs, neutralizes the positive charges of $\varepsilon$-amino groups on lysine residues, relaxes chromatin structure, and increases accessibility for the transcription machinery. Conversely, removal of acetyl groups from histones and other nuclear proteins by HDACs induces chromatin condensation and transcriptional repression. ${ }^{[2]}$

HDACs are expressed in all eukaryotic cells, and HDAC activity is essential for cell proliferation, differentiation, and homeostasis. Eighteen HDACs have been identified in humans and are classified on the basis of their homology to yeast HDACs. Eleven of these HDACs contain highly conserved deacetylase domains, are zinc-dependent enzymes, and are divided into class I (HDAC1, $-2,-3$, and -8 , homologues of yeast RPD3), class lla (HDAC4, -5, -7, and -9 homologues of yeast HDA1), class IIb (HDAC6 and -10, having two catalytic domains), and class IV HDACs (HDAC11, the only member of this class, HDAC11 has less sequence similarity with both class I and II deacetylases). Overexpression of specific HDACs has been observed in many types of cancer, and often correlates with poor prognosis. ${ }^{[3]}$

HDAC inhibition induced by HDAC inhibitors (HDACi) may regulate gene expression, both directly and indirectly, by hyperacetylation of histones and/or transcription factors such as NF- $\mathrm{B}$, STAT1, STAT3, YY1, E2F, and Rb. In cancer cells, HDACi 
induce cell-cycle arrest by up-regulation of p21 and/ or down-regulation of cyclins, suppress angiogenesis by decreased expression of pro-angiogenic factors (VEGF, HIF-1 $\alpha$ ), and modulate the release of cytokines (TNF- $\alpha$, interleukin-1). ${ }^{[4]}$ Thus, HDACi and their development have become the subject of intense interest by both academic and industrial scientists, and many of them have now entered the clinical arena. ${ }^{[3 a]}$

Multiple classes of HDACi have been developed, and members of these classes differ substantially in their potency and target specificity. Among them, vorinostat (suberoylanilide hydroxamic acid, SAHA) and romidepsin (FK-228) were approved by the US Food and Drug Administration (FDA) in 2006 and 2009 , respectively, for the treatment of refractory cutaneous T-cell lymphoma (CTCL). ${ }^{[5]}$ In addition, valproic acid (VPA), panobinostat (LBH589), belinostat (PDX101), givinostat (ITF2357), resminostat (4SC-201), entinostat (MS-275), and mocetinostat (MGCD0103) (Figure 1) are examples of HDACi entered into phase II/III clinical trials, alone or in combination with other chemotherapeutics for the therapy of hematological disorders and/or solid tumors. ${ }^{[3 a]}$

According to the well-known pharmacophore model for $\mathrm{HDACi}^{[6]}$ a deacetylase inhibitor should bear a CAP group to interact with the rim of the catalytic tunnel of the enzyme, a connection unit, linking the CAP to a hydrophobic spacer (HS) and lying into the tunnel, and an enzyme inhibiting group (EIG), able to complex the zinc ion, crucial for the catalysis at the bottom of the tunnel. From 2001, our research group has described various chemically different series of HDACi [aroylpyrrolylhydroxamates (APHAs) and (aryloxopropenyl)pyrrolylhydroxamates $\mathbf{1}^{[7]}$ aroyl/arylamino-, (phenyloxopropenyl)-, and (amidopropenyl)cinnamyl and -pyridinylpropenoic hydroxamates $2_{1}^{[8]}$ and uracil-based hydroxamates and 2-aminoanilides (UBHAs) 3], ${ }^{[9]}$ fitting with this pharmacophore model (Figure 2).

Some analogues of $\mathbf{1}$, namely MC1575 and MC1568, displayed class-II-selective HDAC inhibitory activity, and have been used as valuable tools to dissect the role of class II HDACs in a number of different biological contexts. ${ }^{[10]}$ Some derivatives of $\mathbf{2}$ and $\mathbf{3}$ showed high anticancer effects. Recently, several authors highlighted structurally different HDACi bearing the $\mathrm{N}$-tert-butyloxycarbonyl (Boc)-amino group at the CAP moiety (compounds 4-7; Figure 2). Such compounds showed anti-HDAC6 specific activity and synergis-
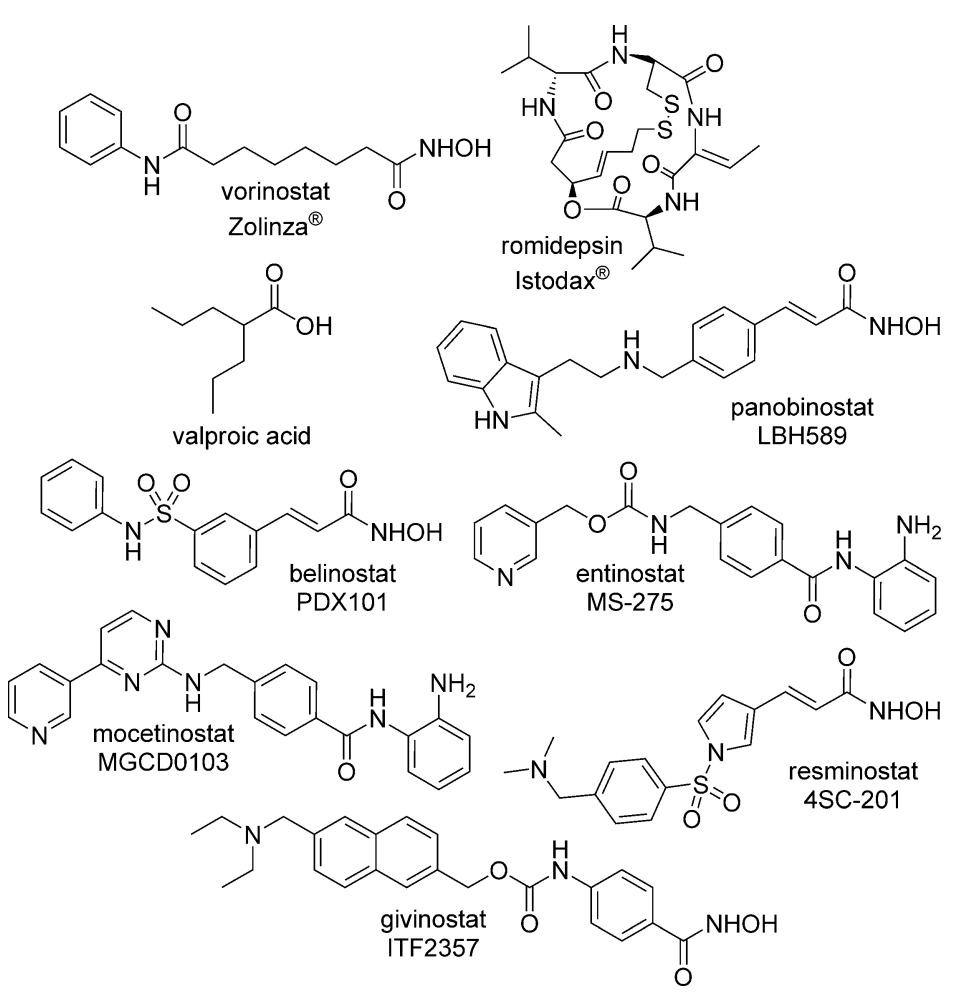

Figure 1. HDACi approved by the FDA and/or in clinical trials.<smiles>[Y]C(=O)[Y]1ccc(/C=C/C(=O)NO)n1C</smiles>

$\mathrm{X}=$ none, $\mathrm{CH}=\mathrm{CH} ; \mathrm{Y}=\left(\mathrm{CH}_{2}\right)_{n}$; $n=0-7 ; \mathrm{Ar}=($ hetero)aryl

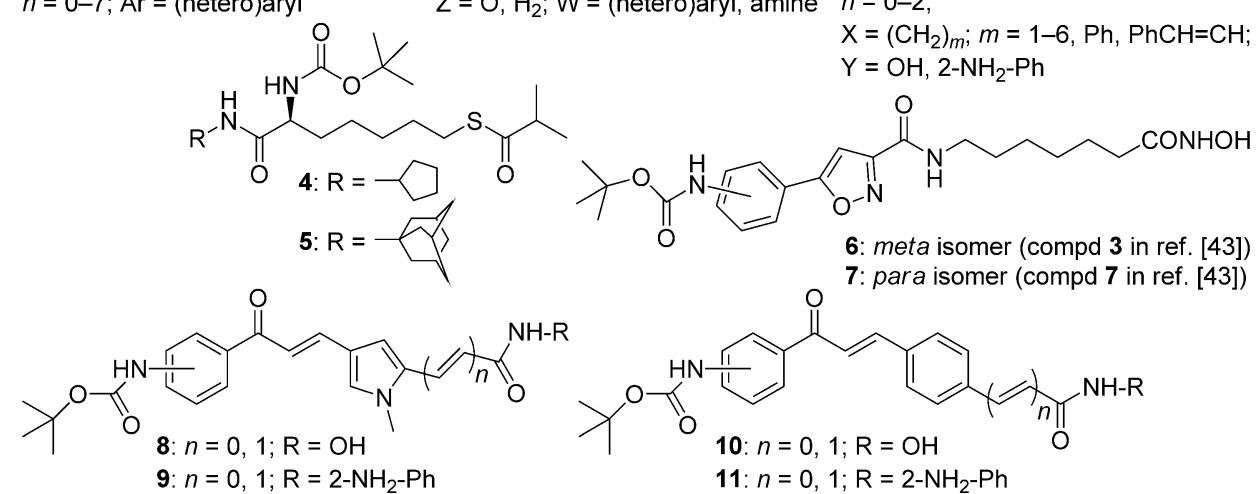

Figure 2. Design of novel HDAC inhibitors.

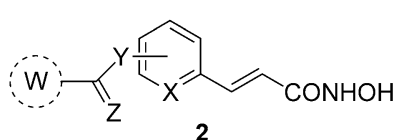
$X=\mathrm{CH}, \mathrm{N} ; \mathrm{Y}=\mathrm{CH}=\mathrm{CH}, \mathrm{NH}$; $\mathrm{Z}=\mathrm{O}, \mathrm{H}_{2} ; \mathrm{W}=$ (hetero)aryl, amine $n=0-2$<smiles>[Y]NC(=O)CSc1nc(C)cc(=O)[nH]1</smiles>
$\mathrm{X}=\left(\mathrm{CH}_{2}\right)_{m} ; m=1-6, \mathrm{Ph}, \mathrm{PhCH}=\mathrm{CH}$; $\mathrm{Y}=\mathrm{OH}, 2-\mathrm{NH}_{2}-\mathrm{Ph}$

tic inhibition of HCT116 cancer cell growth when used in combination with paclitaxel, ${ }^{[11]}$ inhibition of the estrogen-stimulated growth of human breast cancer MCF7 cells, ${ }^{[11]}$ and block the proliferation of a panel of pancreatic cancer cell lines. ${ }^{[12]}$ Thus, prompted by the interest aroused by the insertion of a Bocamino moiety at the CAP group, we designed and synthesized a series of analogues of $\mathbf{1}$ and $\mathbf{2}$ containing this chemical feature at the CAP benzene ring, and carrying as EIG either the 
hydroxamate $(\mathbf{8}, \mathbf{1 0})$ or the 2 aminoanilide $(9,11)$ moiety (Figure 2).

All the new derivatives 8-11 were tested at $5 \mu \mathrm{m}$ against human recombinant (hr) HDAC1 and -4 , and for selected compounds $I C_{50}$ values (compound dose required to inhibit enzyme activity by $50 \%$ ) were determined against all the HDAC1-11 isoforms. Compounds 8-11 were also assayed in human leukemia U937 cells to determine their effects on cell cycle, apoptosis induction, and granulocytic differentiation after treatment for $30 \mathrm{~h}$. The most pro-apoptotic derivatives were then tested in three different cancer cell lines to assess their antiproliferative activities, and the most potent compound was further characterized (antiproliferative activity against a wider panel of cancer cells, histone $\mathrm{H} 3$ acetylation, clonogenic assay) as a valuable anticancer agent.

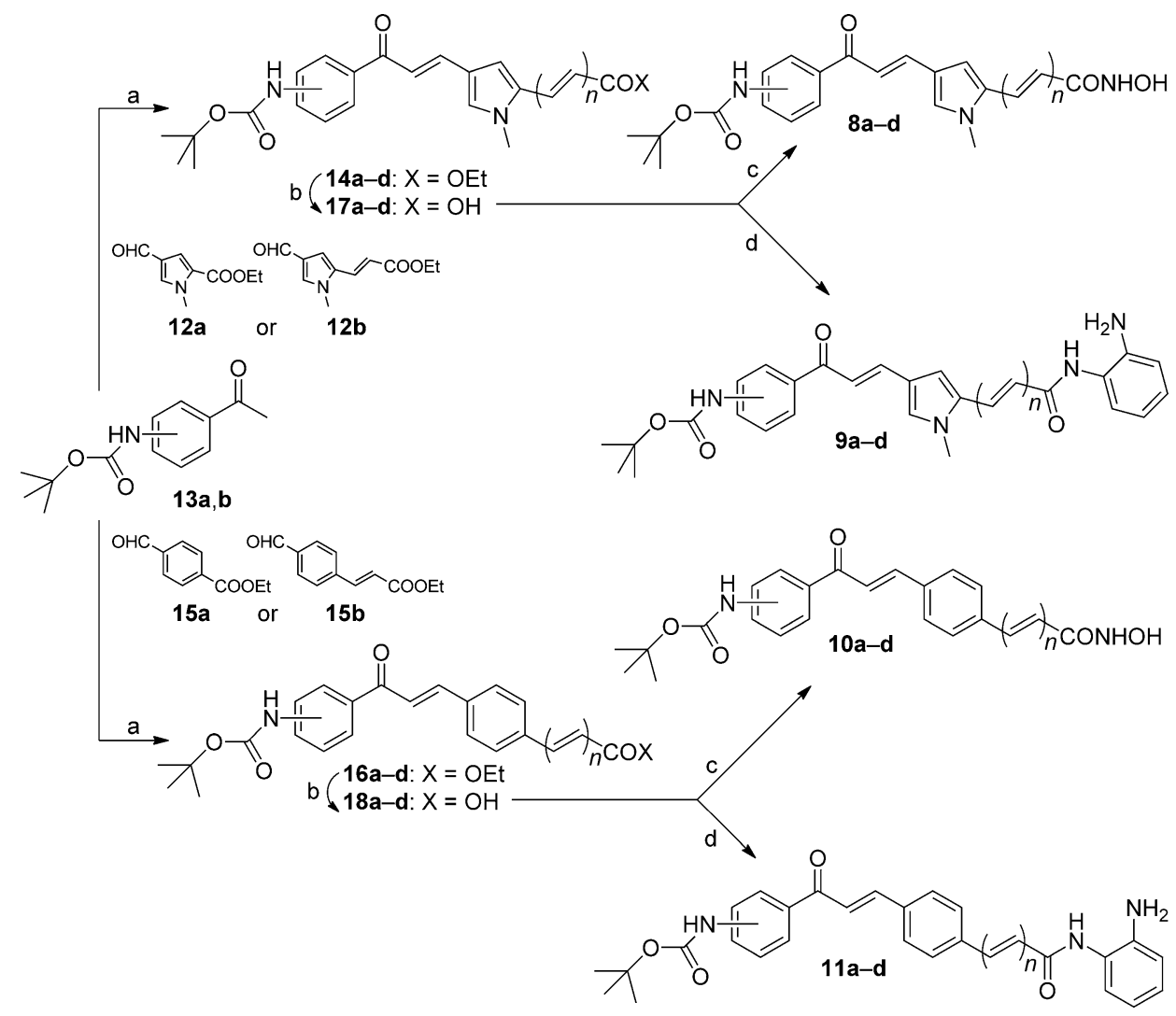

Scheme 1. Reagents and conditions: a) $\mathrm{C}_{2} \mathrm{H}_{5} \mathrm{ONa}$, anhyd. $\mathrm{C}_{2} \mathrm{H}_{5} \mathrm{OH}, \mathrm{RT}, 2 \mathrm{~h}$; b) $\mathrm{LiOH}, \mathrm{THF} / \mathrm{H}_{2} \mathrm{O}$, overnight; c) 1. $\mathrm{ClCOOC}_{2} \mathrm{H}_{5},\left(\mathrm{C}_{2} \mathrm{H}_{5}\right)_{3} \mathrm{~N}$, anhyd. THF, $0^{\circ} \mathrm{C}, 30 \mathrm{~min}, 2 . \mathrm{CH}_{3} \mathrm{O}\left(\mathrm{CH}_{3}\right)_{2} \mathrm{ONH}_{2}$, anhyd. THF, $0^{\circ} \mathrm{C}, 1 \mathrm{~h}$, 3. Amberlyst 15 , $\mathrm{CH}_{3} \mathrm{OH}, \mathrm{RT}, 1.5 \mathrm{~h}$; d) 1. $\left(\mathrm{C}_{2} \mathrm{H}_{5}\right)_{3} \mathrm{~N}$, BOP reagent, anhyd. DMF, $\mathrm{N}_{2(\mathrm{~g})}, \mathrm{RT}$, 2. o-phenylendiamine, anhyd. DMF, $\mathrm{N}_{2(\mathrm{~g}),} \mathrm{RT}$, $1 \mathrm{~h}$.

\section{Results and Discussion}

\section{Chemistry}

Aldol condensation of commer-

cially available ethyl 4-formyl-1-methyl-1H-pyrrole-2-carboxylate $12 \mathrm{a}$ or ethyl 3-(4-formyl-1-methyl-1H-pyrrol-2-yl)acrylate $12 b^{[7 e]}$ with 3- or 4-tert-butoxycarbonylaminoacetophenones $13 \mathbf{a}, \mathbf{b}$ was carried out in dry ethanol in the presence of sodium ethylate and afforded the pyrrole-containing ethyl esters $14 \mathbf{a}-\mathbf{d}$ (Scheme 1). The same reaction performed starting from ethyl 4-formylbenzoate or ethyl-(4-formylphenyl)acrylate 15 a,b furnished the ethyl benzoates/cinnamates $16 \mathbf{a}-\mathbf{d}$. The esters 14 and 16 were then hydrolyzed with lithium hydroxide in tetrahydrofuran/water to afford the corresponding carboxylic/acrylic acids 17 and 18, key intermediates for the synthesis of the related hydroxamates (reaction with ethyl chloroformate/triethylamine followed by addition of O-(2-methoxy-2-propyl)hydroxylamine and final acidic treatment with the Amberlyst 15) $\mathbf{8}, \mathbf{1 0}$ or 2'-aminoanilides [treatment with benzotriazole-1-yloxytris(dimethylamino)phosphonium hexafluorophosphate (BOP reagent, Castro's reagent), ortho-phenylendiamine, and $\left(\mathrm{C}_{2} \mathrm{H}_{5}\right)_{3} \mathrm{~N}$ in dry $\mathrm{N}, \mathrm{N}$-dimethylformamide] 9, 11 . Chemical and physical data of compounds 8-11 are listed in Table 1. Chemical and physical data of the intermediate compounds 14, 16-18 are listed in table S1 in the Supporting Information.

\section{Human recombinant HDAC1 and HDAC4 assays}

Compounds 8-11 were tested at $5 \mu \mathrm{M}$ against hrHDAC1 (substrate: histone $\mathrm{H} 3$ ) and hrHDAC4 (substrate: the non-histone trifluoroacetyllysine derivative), ${ }^{[13]}$ and the results are summarized in Table 2. Among the hydroxamates 8 and 10, the benzene compounds 10 showed, in general, similar or better potency against HDAC1 than the corresponding pyrrole analogues (with the exception of $10 \mathrm{~d}$ ) but lower than SAHA and, with some exceptions (10 c and $\mathbf{8 c}$ ), than MS-275, used as reference drugs.

Typically, 3-NH-Boc-substituted compounds were more efficient than their 4-NH-Boc counterparts, and the arylcarbonyl hydroxamates were less potent than the arylacrylic analogues, at least in the pyrrole series $\mathbf{8}$. However, $10 \mathrm{a}-\mathrm{c}$ and the pyrrole 8 a displayed higher potency than SAHA against HDAC4. Regarding the 2'-aminoanilides 9 and 11, both the pyrrole and benzene derivatives showed low inhibitory potency against HDAC1 if compared with the related hydroxamates, but against HDAC4 the pyrrole compounds 9 (with the exception of $9 \mathrm{a}$ ) were more potent than the corresponding hydroxamates, thus being quite HDAC4-selective. Against HDAC4 the benzene anilides 11, despite a drop of potency when compared with the related hydroxamates, maintained $36-41 \%$ inhibition at $5 \mu \mathrm{M}$. In relation particularly to the pyrrole series $\mathbf{9}$, 
Table 1. Chemical and physical properties of compounds 8-11.

\begin{tabular}{|c|c|c|c|c|c|}
\hline Compd & $\begin{array}{l}\text { NH-Boc } \\
\text { position }\end{array}$ & $n$ & $\mathrm{mp}\left[{ }^{\circ} \mathrm{C}\right]$ & $\begin{array}{l}3 \quad 11 a-d \\
\text { Recrystallization } \\
\text { solvent }\end{array}$ & Yield [\%] \\
\hline $8 a$ & 3 & 0 & $121-123$ & toluene & 77 \\
\hline $8 b$ & 4 & 0 & $102-104$ & toluene & 75 \\
\hline $8 c$ & 3 & 1 & $120-122$ & toluene & 73 \\
\hline $8 d$ & 4 & 1 & $122-124$ & toluene & 75 \\
\hline $9 a$ & 3 & 0 & $185-187$ & acetonitrile & 69 \\
\hline $9 b$ & 4 & 0 & $119-121$ & toluene & 88 \\
\hline $9 c$ & 3 & 1 & $162-164$ & acetonitrile & 72 \\
\hline $9 d$ & 4 & 1 & $220-222$ & methanol & 87 \\
\hline $10 a$ & 3 & 0 & $125-127$ & toluene & 82 \\
\hline $10 \mathrm{~b}$ & 4 & 0 & 190-192 & acetonitrile & 75 \\
\hline $10 \mathrm{c}$ & 3 & 1 & $162-164$ & acetonitrile & 78 \\
\hline $10 d$ & 4 & 1 & $180-182$ & acetonitrile & 81 \\
\hline $11 \mathrm{a}$ & 3 & 0 & $210-212$ & methanol & 67 \\
\hline $11 \mathrm{~b}$ & 4 & 0 & 194-196 & acetonitrile & 74 \\
\hline $11 \mathrm{c}$ & 3 & 1 & 205-207 & methanol & 74 \\
\hline $11 \mathrm{~d}$ & 4 & 1 & $123-125$ & toluene & 59 \\
\hline
\end{tabular}

Effect of compounds 8-11 on $\alpha$-tubulin acetylation in human leukemia U937 cells as an indication of HDAC6 inhibition

Western blot analyses in human leukemia U937 cells were performed on 8-11 (5 $\mu \mathrm{M}, 24 \mathrm{~h})$ to detect their effects on the acetylation level of $\alpha$-tubulin, a marker of HDAC6 inhibition. MS-275 and SAHA $(5 \mu \mathrm{M}, 24 \mathrm{~h})$ were used as reference drugs. Data depicted in Figure 3 show that both pyrrole $(\mathbf{8})$ and benzene (10) hydroxamates were able to strongly increase $\alpha$-tubulin acetylation, with 10 more efficient than 8 . In contrast, the $2^{\prime}$ aminoanilides 9 and 11 (including the reference MS-275) yielded a signal similar or slightly higher than the control (DMSO).

\begin{tabular}{|c|c|c|}
\hline \multirow[t]{2}{*}{ Compd } & \multicolumn{2}{|c|}{ Inhibition $[\%]^{[a]}$} \\
\hline & HDAC1 & HDAC4 \\
\hline $8 a$ & $37 \pm 0.8$ & $71 \pm 4$ \\
\hline $8 \mathrm{~b}$ & $24 \pm 1$ & $21 \pm 2$ \\
\hline $8 \mathrm{c}$ & $65 \pm 3$ & $60 \pm 3$ \\
\hline $8 d$ & $59 \pm 2$ & $51 \pm 2$ \\
\hline $9 a$ & $22 \pm 2$ & $43 \pm 2$ \\
\hline $9 \mathrm{~b}$ & $11 \pm 1$ & $32 \pm 2$ \\
\hline $9 c$ & $31 \pm 1.2$ & $64 \pm 3$ \\
\hline $9 d$ & $25 \pm 2.1$ & $66 \pm 2.2$ \\
\hline $10 a$ & $43 \pm 1.8$ & $83 \pm 4.4$ \\
\hline $10 \mathrm{~b}$ & $37 \pm 1.1$ & $83 \pm 5.2$ \\
\hline $10 c$ & $65 \pm 2.4$ & $76 \pm 3.2$ \\
\hline $10 \mathrm{~d}$ & $35 \pm 1.8$ & $63 \pm 2.5$ \\
\hline $11 \mathrm{a}$ & $14 \pm 0.9$ & $38 \pm 1.4$ \\
\hline $11 \mathrm{~b}$ & $10 \pm 0.3$ & $36 \pm 2.4$ \\
\hline $11 \mathrm{c}$ & $9 \pm 0.2$ & $41 \pm 1.4$ \\
\hline $11 \mathrm{~d}$ & $11 \pm 0.9$ & $40 \pm 1.3$ \\
\hline SAHA & $87 \pm 2.2$ & $63 \pm 1.3$ \\
\hline MS-275 & $54 \pm 2.1$ & $10 \pm 1.4$ \\
\hline
\end{tabular}

[a] Percent inhibition at $5 \mu \mathrm{m}$; data represent mean values \pm SD of at least three separate experiments.

the introduction of the Boc-amino substituent at the 3-position of the benzene ring seemed to be preferred, and the insertion of a double bond between the carbonyl function and the 2'aminoanilide moiety led to more potent compounds $(\mathbf{9} \mathbf{c}, \mathbf{d})$.

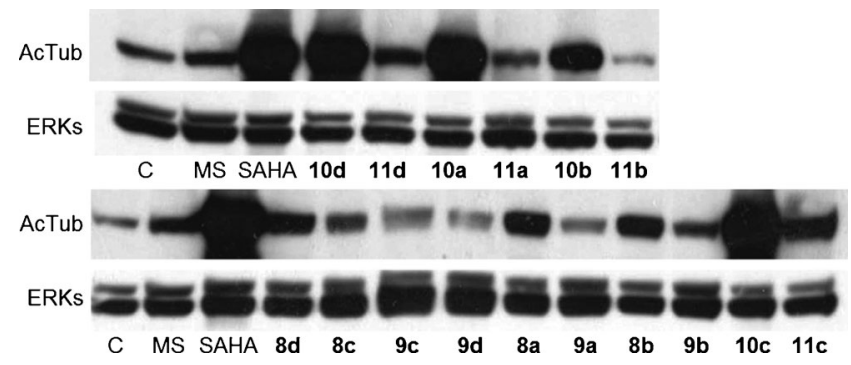

Figure 3. Effects of compounds 8-11, MS-275 (MS), and SAHA (5 $\mu \mathrm{M}, 24 \mathrm{~h}$ ) on $\alpha$-tubulin acetylation (AcTub) in human U937 leukemia cells. Western blot analyses were performed with specific antibodies. ERK proteins were used for equal loading. Blots representative of two independent experiments with similar results are shown.

\section{Profiling of selected compounds $8 b$ and $10 c$ on HDAC1-11 isoforms}

Two selected compounds, $\mathbf{8} \mathbf{b}$ and $\mathbf{1 0}$, chosen because of their effect on tubulin acetylation and their high pro-apoptotic properties in U937 cells (see below), were tested against all the HDAC1-11 isoforms in ten-dose $\mathrm{IC}_{50}$ mode with threefold serial dilution starting from $50 \mu \mathrm{m}$ solutions (Table 3$)$. From these data, the tert-butyl-(3-(3-(4-(3-(hydroxyamino)-3-oxoprop-1-en$1-\mathrm{yl})$ phenyl)acryloyl)phenyl)carbamate $10 \mathrm{c}$ was generally more potent than the tert-butyl (4-(3-(5-(hydroxycarbamoyl)-1methyl-1H-pyrrol-3-yl)acryloyl)phenyl)carbamate $\mathbf{8 b}$ against HDACs (with the exception of HDAC5), and was less efficient than SAHA, used as reference drug. Compound $10 \mathrm{c}$ displayed single-digit micromolar inhibition of HDAC1, $-2,-4,-8$, and -10, and nanomolar activity against HDAC6 $\left(\mathrm{IC}_{50}=10.2 \mathrm{~nm}\right)$. Com- 


\begin{tabular}{|c|c|c|c|}
\hline \multirow[t]{2}{*}{ HDAC } & \multicolumn{3}{|c|}{$\mathrm{IC}_{50}[\mu \mathrm{M}]$} \\
\hline & $8 b$ & $10 c$ & SAHA \\
\hline 1 & 54.8 & 2.9 & 0.26 \\
\hline 2 & $28 \%^{[\mathrm{a}]}$ & 2.1 & 0.92 \\
\hline 3 & 82.2 & 10.8 & 0.35 \\
\hline 4 & 74.4 & 3.2 & 0.49 \\
\hline 5 & 70.6 & 101.0 & 0.38 \\
\hline 6 & 0.03 & 0.01 & 0.03 \\
\hline 7 & $30 \%{ }^{[a]}$ & $34 \%^{[a]}$ & 0.34 \\
\hline 8 & 19.8 & 1.2 & 0.24 \\
\hline 9 & 99.9 & 68.8 & 0.32 \\
\hline 10 & $N A^{[b]}$ & 5.1 & 0.46 \\
\hline 11 & $16 \% \%^{[a]}$ & 12.0 & 0.36 \\
\hline
\end{tabular}

[a] Percent inhibition at $50 \mu \mathrm{m}$. [b] Not active.

pound $\mathbf{8} \mathbf{b}$ was also highly potent against HDAC6, with an $\mathrm{IC}_{50}$ value similar to SAHA $\left(\mathrm{IC}_{50} \mathbf{8} \mathbf{b}=27.9 \mathrm{~nm} ; \mathrm{IC}_{50} \mathrm{SAHA}=28.6 \mathrm{~nm}\right)$, confirming the western blot data on acetyl- $\alpha$-tubulin, and because of its low activities against the other HDAC isoforms, it is extremely HDAC6-selective.

\section{Theoretical binding pose of $10 \mathrm{c}$ in the HDAC6 binding site}

To better rationalize the enhanced inhibitory activity against HDAC6 of the newly discovered compounds, molecular modeling studies were undertaken. As the X-ray structure of HDAC6 has not been solved, a homology-based model of its major functional domain (second catalytic subunit CDIl, G482G801) ${ }^{[14]}$ was constructed. In this step, multiple HDAC X-ray templates and subsequent multiple-threading alignments were employed following the I-TASSER methodology. ${ }^{[15]}$ Interestingly, the same methodology has been already applied by Kozikowski and co-workers to propose viable ligand-HDAC6 theoretical complexes. $^{[16]}$

The resulting HDAC6 model was then used to dock compound $10 \mathrm{c}$, which is among the most active and selective HDAC6 inhibitors described herein. Analysis of the modeled enzyme binding cavity revealed that its outer portion is lined by five loops that could rearrange upon ligand binding. Therefore, to allow for a certain amount of protein plasticity during the docking calculation an induced-fit docking approach (IFD) was used (see the Experimental Section for a full description). In the best ranking binding pose predicted by the IFD (Figure 4), 10 c is well inserted in the enzyme binding cavity with its hydroxamate group coordinating the zinc ion. Moreover, the rigid aromatic spacer is embedded in an aromatic cage formed by H500, F620, and F680 engaging favorable charge-transfer interactions and hydrophobic contacts with P501. On the other hand, the tert-butylcarbamate group at position 3 of the terminal phenyl ring extends toward the outer portion of the binding gorge contacting one of the loops lining the rim of the catalytic tunnel (residues G677-G686). In this position the latter group hydrogen bonds with the F199 backbone $\mathrm{CO}$ group and engages in hydrophobic contacts with the M682 side chain. Analysis of the results obtained for

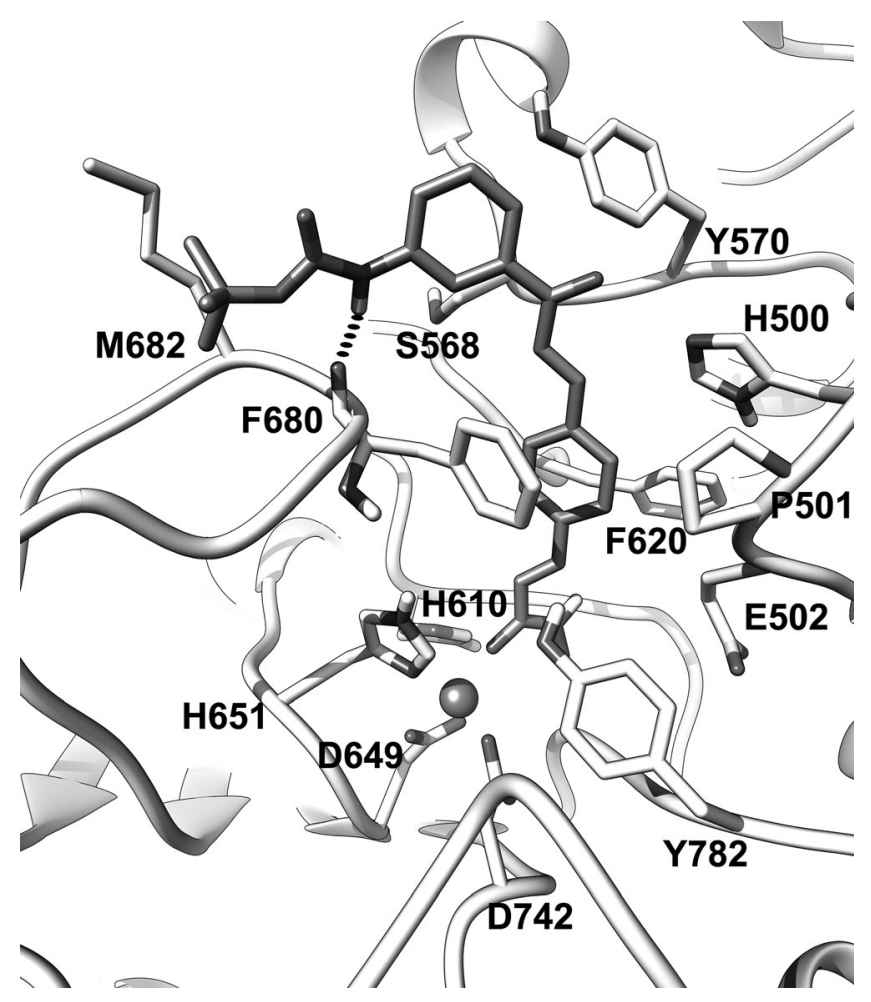

Figure 4. Predicted binding pose of $10 \mathrm{c}$ in the HDAC6 homology model. The ligand is represented as dark-gray sticks, whereas the enzyme is represented as white sticks. Hydrogen bonds are displayed as black dashed lines.

$10 \mathrm{~d}$ (figure S1 in the Supporting Information) revealed that the ligand is unable to form the aforementioned hydrogen bond interaction with the enzyme while the hydrophobic contacts with M682 are maintained.

According to these calculations, the Boc-unsubstituted $N$-hydroxy-3-(4-(3-oxo-3-phenylprop-1-en-1-yl)phenyl)acrylamide would be unable to establish the same interaction pattern contacts with the outer portion of the enzyme. These data would explain why $10 \mathrm{c}\left(\mathrm{IC}_{50} 0.01 \mu \mathrm{M}\right)$ is a more potent HDAC6i than its close analogue $10 \mathrm{~d}$ or the Boc-unsubstituted prototype $\left(\mathrm{IC}_{50}=0.04 \mu \mathrm{M}\right.$ and $0.5 \mu \mathrm{m}$, respectively).

Effect of compounds 8-11 on cell-cycle distribution, apoptosis induction, and granulocytic differentiation in human U937 leukemia cells

The described compounds 8-11 were tested at $5 \mu \mathrm{m}$ for $30 \mathrm{~h}$ in U937 cells to determine their effects on cell cycle, apoptosis induction, and granulocytic differentiation (Figure 5). SAHA and MS-275 $(5 \mu \mathrm{M})$ were used as reference drugs. Among the hydroxamates $8, \mathbf{1 0}$, the compounds $8 \mathrm{a}, \mathbf{8 b}$, and $10 \mathrm{c}$ displayed an arrest in the $G_{1}$ phase similar to $(\mathbf{1 0} c)$ or higher than (8a, $\mathbf{8 b}$ ) MS-275. Compound $\mathbf{8 c}$ blocked the cycle at the $S$ phase, similar to SAHA. In relation to the 2 '-aminoanilides, the benzene compounds $\mathbf{1 1} \mathbf{a}$,b showed a block at the $G_{1}$ phase similar to MS-275, whereas the remaining derivatives produced a weaker effect (Figure $5 \mathrm{a}$ ). Taking into account the pre- $\mathrm{G}_{1}$ peak as an index of pro-apoptotic properties of the com- 

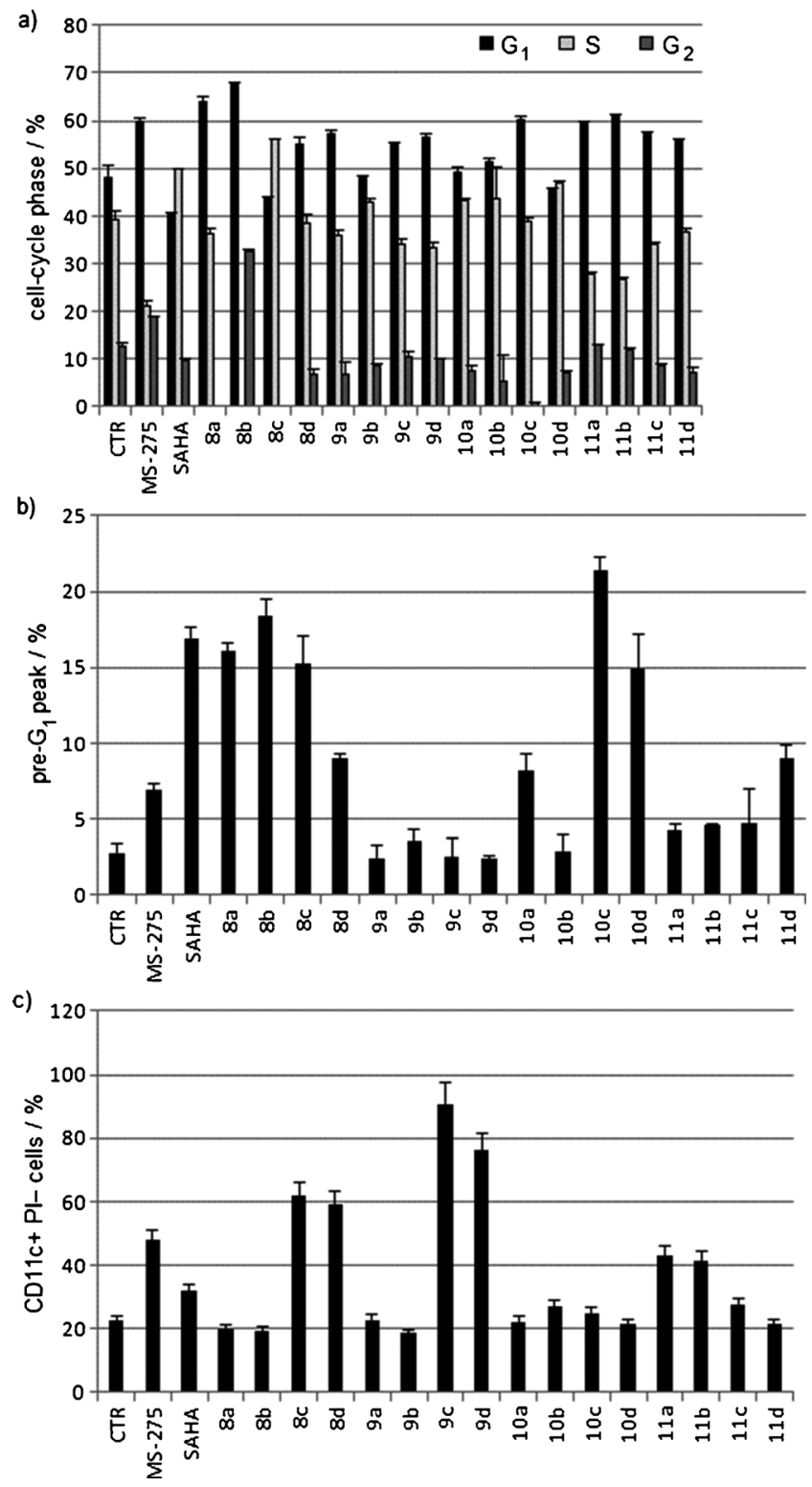

Figure 5. a) Cell-cycle analysis, b) apoptosis induction, and c) granulocytic differentiation in human U937 leukemia cells treated with compounds 8-11, SAHA, and MS-275 at $5 \mu \mathrm{m}$ for $30 \mathrm{~h}$.

pounds, Figure $5 \mathrm{~b}$ shows that the hydroxamates $8 \mathrm{a}-\mathrm{c}$ and $10 \mathbf{c}, \mathbf{d}$ exhibited 15- $21 \%$ apoptotic induction in this assay, with $\mathbf{8 b}$ and $10 \mathrm{c}$ being more potent than SAHA [percent pre$\mathrm{G}_{1}$ peak: $18.4(\mathbf{8} \mathbf{b}), 21.4(\mathbf{1 0} \mathrm{c})$, and $\left.16.9 \%(\mathrm{SAHA})\right]$.

The expression of the surface antigen CD11c was determined as a marker of granulocytic differentiation in U937 leukemia cells. The cells were treated with 8-11 at $5 \mu \mathrm{m}$ for $30 \mathrm{~h}$, and then the percentage values of CD11c-positive/propidium iodide (PI)-negative cells were determined. In this assay, both the pyrrole hydroxamates $(\mathbf{8} \mathbf{c}, \mathbf{d})$ and 2-aminoanilides $(\mathbf{9} \mathbf{c}, \mathbf{d})$ were able to induce cytodifferentiation effects more potently than MS-275, one of the most efficient cytodifferentiating agents among the HDAC inhibitors described in literature. ${ }^{[9 e, 17]}$ In particular, 9c and $\mathbf{9 d}$ displayed respectively 90.9 and $76.1 \%$ of $\mathrm{CD} 11 \mathrm{c}+/ \mathrm{PI}-$ cells (Figure $5 \mathrm{c}$ ).
Antiproliferative activities of selected compounds in a panel of different cancer cell lines

Selected pro-apoptotic compounds $(\mathbf{8} a, 8 b, \mathbf{1 0} c$, and $\mathbf{1 0 d}$ ) were first tested in three different human cancer cell lines (colon carcinoma HCT116, non-small-cell lung adenocarcinoma A549, and chronic myeloid leukemia K562), using the CellTiterGlo luminescent cell viability assay, to determine their antiproliferative effects after $72 \mathrm{~h}$ of treatment (Table 4). The benzene

\begin{tabular}{|lccc|}
\hline $\begin{array}{l}\text { Table 4. In vitro antiproliferative effects of selected compounds against } \\
\text { cancer cell lines. } \\
\text { Compd }\end{array}$ & $\mathrm{IC}_{50}[\mu \mathrm{M}]^{[\mathrm{a}]}$ & $\mathrm{K} 562$ \\
\hline $\mathbf{8} \mathbf{a}$ & $\mathrm{HCT} 116$ & 12.2 & 1.5 \\
$\mathbf{8} \mathbf{b}$ & 3.6 & 18.8 & 3.1 \\
$\mathbf{1 0} \mathbf{C}$ & 9.7 & 4.1 & 0.6 \\
$\mathbf{1 0} \mathbf{d}$ & 1.0 & 3.1 & 1.6 \\
\hline
\end{tabular}

[a] Concentration of test compound required for $50 \%$ inhibition of cell viability. Determined by CellTiter-Glo assays $(72 \mathrm{~h})$, performed in replicate $(n \geq 2)$; values are shown are the mean (SD $<30 \%$ of the mean). HCT116: human colon carcinoma, A549: human non-small-cell lung adenocarcinoma, K562: chronic myeloid leukemia.

hydroxamates $10 \mathrm{c}$ and $10 \mathrm{~d}$ showed the highest antiproliferative activities in these assays, with $\mathrm{IC}_{50}$ values ranging from 0.6 to $4.1 \mu \mathrm{m}$. Thus, we selected the tert-butyl-3-(3-(4-(3-(hydroxyamino)-3-oxoprop-1-en-1-yl)phenyl)acryloyl)phenylcarbamate $10 \mathrm{c}$ to extend the characterization against a panel of different cancer cells (colon carcinoma HT29, melanoma M14, nonsmall-cell lung adenocarcinoma H1299, breast adenocarcinoma MCF7, ovarian carcinoma HEY, glioblastoma U87, neuroblastoma LAN-5 and SH-SY5Y, pancreatic carcinoma PANC-1, prostate carcinoma PC3, and ovarian carcinoma SKOV3 cancer cells) after $48 \mathrm{~h}$ treatment, using the 3-(4,5-dimethylthiazol-2-yl)-2,5diphenyltetrazolium bromide (MTT) method (Table 5).

Table 5. In vitro antiproliferative activity of $10 \mathrm{c}$ against a panel of cancer cell lines.

Cell line $\mathrm{IC}_{50}[\mu \mathrm{M}]^{[\mathrm{a}]}$

colon carcinoma HT29

melanoma M14

non-small-cell lung adenocarcinoma H1299

breast carcinoma MCF7

ovarian carcinoma HEY

ovarian carcinoma SKOV3

glioblastoma U87

neuroblastoma LAN-5

neuroblastoma SH-SY5Y

pancreatic carcinoma PANC-1

prostate carcinoma PC3

3.2

3.2
21

2.2

2.2
21

20

40

13

0.4

0.6

28

24.5

[a] Concentration of $10 \mathrm{c}$ required for $50 \%$ inhibition of cell viability. Determined by MTT assay; cells were treated with $10 \mathrm{c}$ ranging from 0.1 to $100 \mu \mathrm{M}$ for $48 \mathrm{~h}$. The results are reported as the average of two or three independent experiments (SD $<30 \%$ of the mean). 
In these assays, the two neuroblastoma LAN-5 and SH-SY5Y cell lines were the most sensitive, with $10 \mathrm{c}$ displaying sub-micromolar antiproliferative activities, followed by $\mathrm{H} 1229$ and HT29 carcinoma cells (10c active at single-digit micromolar range), whereas the other screened cell lines were less susceptible to the treatment.

Effects of $10 \mathrm{c}$ in HT29 cells: histone H3 acetylation, proliferation, and colony-forming ability in HT29 cells

Choosing colon HT29 as a representative cancer cell line, the effect of $10 \mathrm{c}$ on acetylation level of histone $\mathrm{H} 3(10 \mu \mathrm{M}, 24 \mathrm{~h})$ was detected by western blot analysis. SAHA was used at $50 \mu \mathrm{M}$ as reference drug. As depicted in Figure $6 \mathrm{a}$, an increased acetylation at Lys $9 / 14$ of histone $\mathrm{H} 3$ was observed after exposure to $10 \mathrm{c}$ when compared with untreated cells.

To further characterize the antiproliferative effect of $10 \mathrm{c}$ in HT29 cells, experiments were performed by treating cells for $24 \mathrm{~h}$ with the compound $(0.5,1$, and $5 \mu \mathrm{M})$ and assessing cell proliferation both at the end of treatment and from 24 to $96 \mathrm{~h}$ after the end of treatment (Figure $6 \mathrm{~b}$ ). As reported in Figure $6 \mathrm{~b}, 10 \mathrm{c}$ induced a dose-dependent decrease of cell survival up to $16 \%(5 \mu \mathrm{M}, 96 \mathrm{~h}$ after the end of treatment). SAHA, tested at the same conditions, was less effective (see figure $\mathrm{S} 2$ in Supporting Information).

Finally, we assessed the ability of HT29 cells to form colonies after treatment with $10 \mathrm{c}(0.5,1.0$, and $5.0 \mu \mathrm{M}$, for $24 \mathrm{~h})$. As reported in Figure $6 \mathrm{c}$, a dose-dependent decrease in colonyforming potential was evident in HT29 cells after $10 \mathrm{c}$ treatment. In particular, an approximate $60 \%$ reduction was observed after exposure to $5 \mu \mathrm{M} 10 \mathrm{c}$ for $24 \mathrm{~h}$ as compared with control untreated cells.

\section{Conclusions}

Using HDAC6-selective inhibitors 4-7, which bear the NH-Boc group at the CAP moiety and show growth inhibition of colon HCT116, estrogen-stimulated breast MCF7, and a panel of pancreatic carcinoma cell lines as a structural basis, we designed, new pyrrole- and benzene-containing hydroxamates $(\mathbf{8}, \mathbf{1 0})$ and 2 -aminoanilides $(\mathbf{9}, \mathbf{1 1})$. These compounds $(\mathbf{8}, \mathbf{1 0}, \mathbf{9}, \mathbf{1 1})$ are substituted with a $\mathrm{NH}-\mathrm{Boc}$ group either at the 3- or 4-position of the benzoyl group and are therefore analogues of compounds 1, 2 previously described by us and endowed with anticancer properties. ${ }^{[7, h, 8 b, d, f, 9 b, c, e, 17,18]}$ When tested against HDAC1 and -4, the 3-NH-Boc-substituted compounds seemed to be more potent than the corresponding 4-NH-Boc counterparts. The benzene hydroxamates $\mathbf{1 0}$ displayed higher inhibition than the related pyrrole analogues $\mathbf{8}$, and exhibited a great decrease in activity when changed into 2 '-aminoanilides (11). In the pyrrole series a similar decrease of potency from hydroxamates $\mathbf{8}$ to anilides $\mathbf{9}$ was not registered. Both the pyrrole (8) and benzene (10) hydroxamates increased the acetylation level of $\alpha$-tubulin in human leukemia U937 cells, a marker of HDAC6 inhibition, whereas both the anilides (9, 11) did not. Two compounds, $\mathbf{8} \mathbf{b}$ and $\mathbf{1 0} c$, were tested on all the HDAC1-11 isoforms, and in agreement with previous data, a)

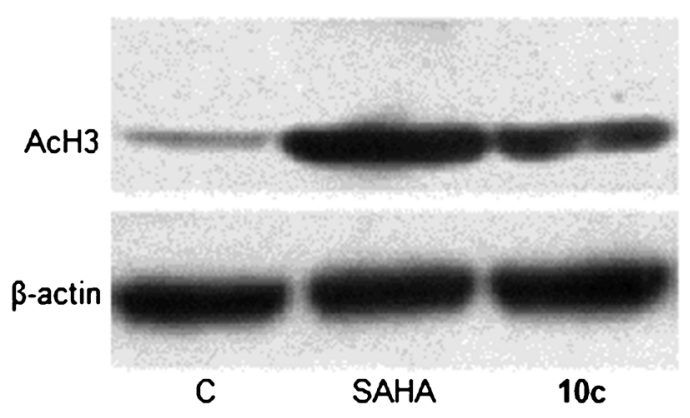

b)

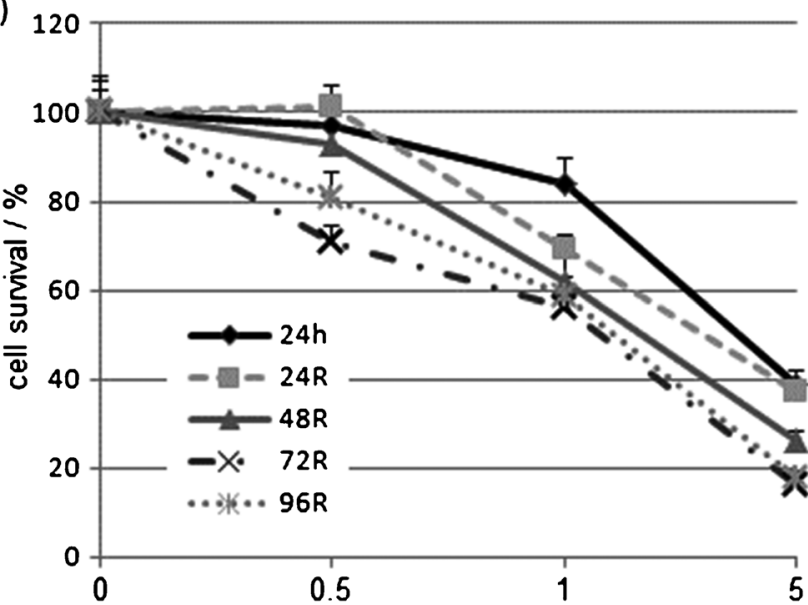

c)

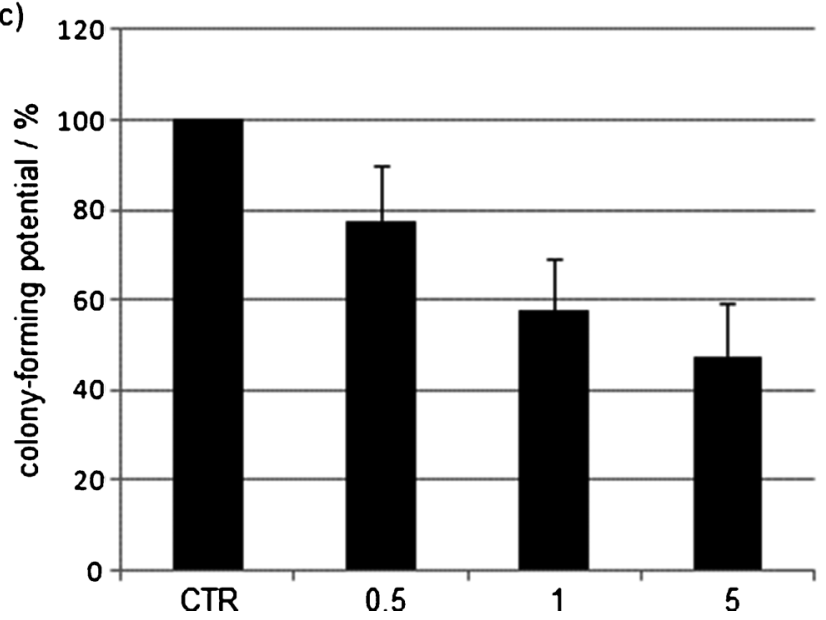

Figure 6. Effects of $10 \mathrm{c}$ in human colon HT29 cancer cells: a) Western blot analysis of acetylated histone $\mathrm{H} 3$ on Lys 9/14 (Ac-H3) in protein extracts obtained after treatment of HT29 cells with $10 \mathrm{c}(10 \mu \mathrm{M})$ and SAHA $(50 \mu \mathrm{M})$ for $24 \mathrm{~h}$. $\beta$-Actin is shown as loading and transferring control. A blot representative of two independent experiments with similar results is shown. b) Percentage of cell survival after treatment with $10 \mathrm{c}$ at doses ranging from 0.5 to $5 \mu \mathrm{M}$ for $24 \mathrm{~h}$. Analysis was performed at the end of treatment ( $24 \mathrm{~h})$, and $24(24 \mathrm{R}), 48(48 \mathrm{R}), 72(72 \mathrm{R})$, and $96 \mathrm{~h}(96 \mathrm{R})$ after the end of treatment $(\mathrm{R}=\mathrm{re}-$ covery). The results are reported as (viability of treated cells)/(viability of control cells $) \times 100$, and represent the average $\pm S D$ of three independent experiments. c) In vitro clonogenic ability of HT29 cells after treatment with $10 \mathrm{c}$ at doses ranging from 0.5 to $5 \mu \mathrm{M}$ for $24 \mathrm{~h}$.

$10 \mathrm{c}$ was more potent than $\mathbf{8} \mathrm{b}$ in 10 of the 11 tested isoforms, and both the compounds showed HDAC6 inhibition at a nanomolar level, $\mathbf{8} \mathbf{b}$ being threefold less potent than $10 \mathrm{c}$ but extremely more selective because of its low potency against the other enzymes. In comparison with other known HDAC6-selec- 
tive inhibitors-such as the Boc-containing compounds 4$7^{[11,12]}$ the tetrahydropyrido[4,3-b]indole derivative tubastati$n A^{[16]}$ or the macrocyclic hydroxamates (S)-9, (S)-34, and (S)$\mathbf{3 5} 5^{[19]}$ - compounds $\mathbf{8} \mathrm{b}$ and $\mathbf{1 0} \mathrm{c}$ displayed similar potency and/ or selectivity, despite some chemical differences shown mainly at the CAP and HS level in the structures.

In U937 cells, $\mathbf{8 b}$ and $10 \mathrm{c}(5 \mu \mathrm{M}, 30 \mathrm{~h})$ induced greater apoptosis (18.4 and $21.4 \%$ ) than SAHA (16.9\%), and the pyrrole $2^{\prime}$-aminoanilides $9 \mathrm{c}$ and $9 \mathrm{~d}(5 \mu \mathrm{M}, 30 \mathrm{~h})$ showed the highest cytodifferentiating effect (76.1 and 90.9\%). When tested against a wide panel of different cancer cell lines, $10 \mathrm{c}$ showed low or single-digit micromolar antiproliferative effect, probably related to its ability to inhibit HDAC1 and -2, largely overexpressed in cancer. ${ }^{[3, d]}$ Remarkably, against neuroblastoma LAN5 and SH-SY5Y cell lines $10 \mathrm{c}$ exerted growth inhibition at nanomolar level, suggesting an additional role for HDAC6 inhibition in neurologic diseases. ${ }^{[20]}$ In colon HT29 cell line, chosen as a representative cell line, $10 \mathrm{c}$ increased the level of histone $\mathrm{H} 3$ acetylation $(10 \mu \mathrm{M}, 24 \mathrm{~h})$, and decreased up to $60 \%$ the colony-forming potential in a dose-dependent manner. Further studies with $10 \mathrm{c}$ in vivo are required to assess its potential use as anticancer agent.

\section{Experimental Section}

\section{Chemistry}

Melting points were determined on a Büchi 530 melting point apparatus and are uncorrected. ${ }^{1} \mathrm{H}$ NMR and ${ }^{13} \mathrm{C}$ NMR spectra were recorded at $400 \mathrm{MHz}$ on a Bruker AC 400 spectrometer; chemical shifts $(\delta)$ are reported in ppm relative to the internal reference tetramethylsilane. EIMS data were recorded with a Fisons Trio 1000 spectrometer; only molecular ions $[M]^{+}$and base peaks are given. All compounds were routinely checked by TLC, ${ }^{1} \mathrm{H} N M R$ and ${ }^{13} \mathrm{C}$ NMR spectra. TLC was performed on aluminum-backed silica gel plates (Merck DC, Alufolien Kieselgel $60 \mathrm{~F}_{254}$ ) with spots visualized by UV light. All solvents were reagent grade and, when necessary, were purified and dried by standard methods. Concentration of solutions after reactions and extractions involved the use of a rotary evaporator operating at reduced pressure of $\sim 20$ Torr. Organic solutions were dried over anhydrous $\mathrm{Na}_{2} \mathrm{SO}_{4}$. Elemental analysis was used to determine purity of the described compounds, that is $>95 \%$. Analytical results are within $\pm 0.40 \%$ of the theoretical values. All chemicals were purchased from Aldrich Chimica, Milan (Italy) or from Alfa Aesar, Milan (Italy), and were of the highest purity.

General procedure for the synthesis of the esters 14 and 16 . Example: Synthesis of ethyl 3-(4-(3-(4-((tert-butoxycarbonyl)amino)phenyl)-3-oxoprop-1-enyl)phenyl)acrylate ( $16 \mathrm{~d})$ : tert-Butyl 4acetylphenylcarbamate $13 \mathrm{~b}(2.12 \mathrm{mmol}, 0.5 \mathrm{~g})$ and ethyl 3-(4-formylphenyl)acrylate $15 \mathrm{~b}(2.12 \mathrm{mmol}, 0.433 \mathrm{~g})$ were added to a solution of $\mathrm{Na}^{0}$ ( $\left.2.54 \mathrm{mmol}, 0.05 \mathrm{~g}\right)$ in $\mathrm{C}_{2} \mathrm{H}_{5} \mathrm{OH}(5 \mathrm{~mL})$. The resulting mixture was stirred at room temperature for $4 \mathrm{~h}$. The reaction was quenched with $\mathrm{H}_{2} \mathrm{O}(30 \mathrm{~mL})$ and extracted with EtOAc $(3 \times 50 \mathrm{~mL})$. The combined organic extracts were washed with saturated $\mathrm{NaCl}$ solution $(3 \times 50 \mathrm{~mL})$, dried with $\mathrm{Na}_{2} \mathrm{SO}_{4}$, and concentrated to obtain a residue that was purified by column chromatography $\left(\mathrm{SiO}_{2}\right.$ eluting with EtOAc/n-hexane $1: 2$ ) to give the compound $16 \mathrm{~d}$ as a pale-yellow solid. ${ }^{1} \mathrm{H}$ NMR $\left(\mathrm{CDCl}_{3}, 400 \mathrm{MHz}\right): \delta=1.33-1.37(\mathrm{t}, 3 \mathrm{H}$, $\left.\mathrm{OCH}_{2} \mathrm{CH}_{3}\right), 1.54\left(\mathrm{~s}, 9 \mathrm{H}, \mathrm{C}\left(\mathrm{CH}_{3}\right)_{3}\right), 4.25-4.31$ (q, $\left.2 \mathrm{H}, \mathrm{OCH}_{2} \mathrm{CH}_{3}\right), 6.47-$ $6.51(\mathrm{~d}, 1 \mathrm{H}, \mathrm{CH}=\mathrm{CHCOOEt}), 6.76$ (bs, $\left.1 \mathrm{H},\left(\mathrm{CH}_{3}\right)_{3} \mathrm{CONH}\right), 7.50-7.71$ $(\mathrm{m}, 8 \mathrm{H}$, benzene protons, $\mathrm{CH}=\mathrm{CHCOOEt}$ and $\mathrm{PhCOCH}=\mathrm{CH}), 7.77-$ $7.81(\mathrm{~d}, 1 \mathrm{H}, \mathrm{PhCOCH}=\mathrm{CH}), 8.00-8.02 \mathrm{ppm}(\mathrm{d}, 2 \mathrm{H}$, benzene protons); ${ }^{13} \mathrm{C} \mathrm{NMR}\left(\mathrm{CDCl}_{3}\right): \delta=28.5(3 \mathrm{C}), 79.5,118.9,121.4,122.1$ (2C), $126.3(4 \mathrm{C}), 130.1(2 \mathrm{C}), 133.5,134.4(2 \mathrm{C}), 141.7,144.0,145.2,153.9$, 161.6, $189.7 \mathrm{ppm}$; MS (El) calcd for $\mathrm{C}_{25} \mathrm{H}_{27} \mathrm{NO}_{5} \mathrm{~m} / \mathrm{z}[\mathrm{M}]^{+}: 421.1889$, found: 421.1885 .

General procedure for the synthesis of the acids 17 and 18. Example: Synthesis of 3-(4-(3-(4-((tert-butoxycarbonyl)amino)phenyl)-3-oxoprop-1-enyl)-1-methyl-1H-pyrrol-2-yl)acrylic acid (17 d): A solution of ethyl 3-(4-(3-(4-((tert-butoxycarbonyl)amino)phenyl)-3oxoprop-1-enyl)-1-methyl-1 $\mathrm{H}$-pyrrol-2-yl)acrylate $14 \mathrm{~d} \quad(0.82 \mathrm{mmol}$, $0.35 \mathrm{~g})$ and $2 \mathrm{~N} \mathrm{KOH}(1.64 \mathrm{mmol}, 0.092 \mathrm{~g})$ in $\mathrm{C}_{2} \mathrm{H}_{5} \mathrm{OH}(15 \mathrm{~mL})$ was stirred overnight at room temperature. Then the solvent was evaporated and $2 \mathrm{~N} \mathrm{HCl}$ was slowly added till the aqueous phase reached $\mathrm{pH}$ 5.0. The colorless solid was filtered and washed first with $\mathrm{H}_{2} \mathrm{O}$ and then with a mixture of $\left(\mathrm{C}_{2} \mathrm{H}_{5}\right)_{2} \mathrm{O}$ /petroleum ether 1:1 to afford pure $17 \mathrm{~d}$. ${ }^{1} \mathrm{H}$ NMR ([D $]$ DMSO, $\left.400 \mathrm{MHz}\right): \delta=1.46(\mathrm{~s}, 9 \mathrm{H}$, $\left.\mathrm{C}\left(\mathrm{CH}_{3}\right)_{3}\right), 3.87\left(\mathrm{~s}, 3 \mathrm{H}, \mathrm{CH}_{3}\right), 6.34(\mathrm{~d}, 1 \mathrm{H}, \mathrm{CH}=\mathrm{CHCOOH}), 7.11(\mathrm{~s}, 1 \mathrm{H}$, pyrrole- $\beta$ proton), $7.26-7.37(\mathrm{~m}, 3 \mathrm{H}$, benzene protons and $\mathrm{PhCOCH}=\mathrm{CH}), 7.57-7.63(\mathrm{~m}, 4 \mathrm{H}$, pyrrole- $\alpha$ proton, benzene protons, $\mathrm{PhCOCH}=\mathrm{CH}$ and $\mathrm{CH}=\mathrm{CHCOOH}), 8.08-8.09(\mathrm{~m}, 1 \mathrm{H}$, benzene proton), 9.52 (bs, $\left.1 \mathrm{H},\left(\mathrm{CH}_{3}\right)_{3} \mathrm{CONH}\right), 13.0 \mathrm{ppm}$ (bs, $1 \mathrm{H}, \mathrm{COOH}$ ); ${ }^{13} \mathrm{C}$ NMR $\quad\left(\left[\mathrm{D}_{6}\right] \mathrm{DMSO}, 400 \mathrm{MHz}\right): \delta=28.5$ (3C), 34.0, 79.5, 104.8, 108.0, 121.6, 122.1 (2C), 123.2, 127.4, 130.1 (2C), 130.6, 133.5, 138.8, $141.7,145.2,153.9,170.6,189.7 \mathrm{ppm}$; MS (EI) calcd for $\mathrm{C}_{22} \mathrm{H}_{24} \mathrm{~N}_{2} \mathrm{O}_{5}$ $\mathrm{m} / \mathrm{z}[M]^{+}: 396.1685$, found: 396.1690 .

General procedure for the synthesis of the hydroxamic acids 8, 10. Example: Synthesis of tert-butyl-(3-(3-(5-(hydroxycarbamoyl)-1-methyl-1 $\mathrm{H}$-pyrrol-3-yl)acryloyl)phenyl)carbamate $\quad(8 \mathrm{a})$ : $\left(\mathrm{C}_{2} \mathrm{H}_{5}\right)_{3} \mathrm{~N} \quad(0.12 \mathrm{mmol}, 0.017 \mathrm{~mL})$ and $\mathrm{ClCOOC}_{2} \mathrm{H}_{5} \quad(0.11 \mathrm{mmol}$, $0.015 \mathrm{~mL})$ were slowly added to a cooled $\left(0^{\circ} \mathrm{C}\right)$ solution of 4-(3-(3((tert-butoxycarbonyl)amino)phenyl)-3-oxoprop-1-enyl)-1-methyl$1 \mathrm{H}$-pyrrole-2-carboxylic acid $17 \mathrm{a}(0.092 \mathrm{mmol}, 0.034 \mathrm{~g})$ in anhydrous THF $(5 \mathrm{~mL})$, and the mixture was stirred for $45 \mathrm{~min}$ at room temperature under $\mathrm{N}_{2}$ atmosphere. Afterward, the solid was filtered, washed with anhydrous THF $(3 \times 5 \mathrm{~mL})$ and then $\mathrm{O}-(2$-methoxy-2-propyl)hydroxylamine $(0.27 \mathrm{mmol}, 0.02 \mathrm{~mL})$ was added, and the resulting mixture was stirred for $15 \mathrm{~min}$ at room temperature. After this time the solvent was removed under vacuum, the residue was diluted in $\mathrm{CH}_{3} \mathrm{OH}(10 \mathrm{~mL})$, and Amberlyst 15 ion-exchange resin $(0.36 \mathrm{~g})$ was added. The mixture was stirred at room temperature for $1 \mathrm{~h}$. After that, the resin was filtered and the filtrate was concentrated under reduced pressure to give crude $\mathbf{8} \mathbf{a}$, which was purified by recrystallization. ${ }^{1} \mathrm{H} N M R \quad\left(\left[\mathrm{D}_{6}\right] \mathrm{DMSO}\right.$, $400 \mathrm{MHz}): \delta=1.50\left(\mathrm{~s}, 9 \mathrm{H}, \mathrm{C}\left(\mathrm{CH}_{3}\right)_{3}\right), 3.94\left(\mathrm{~s}, 3 \mathrm{H}, \mathrm{CH}_{3}\right), 7.04(\mathrm{~s}, 1 \mathrm{H}$, pyrrole- $\beta$ proton), $7.26-7.67(\mathrm{~m}, 6 \mathrm{H}$, benzene proton, $\mathrm{PhCOCH}=\mathrm{CH}$ and $\mathrm{PhCOCH}=\mathrm{CH}), 8.09$ (s, $1 \mathrm{H}$, pyrrole- $\alpha$ proton), 8.99 (bs, $1 \mathrm{H}$, $\left.\left(\mathrm{CH}_{3}\right)_{3} \mathrm{CONH}\right), 9.56$ (bs, $\left.1 \mathrm{H}, \mathrm{CONHOH}\right), 10.95 \mathrm{ppm}$ (bs, $1 \mathrm{H}$, CONHOH); ${ }^{13} \mathrm{C}$ NMR ([D 6 DMSO, $\left.400 \mathrm{MHz}\right): \delta=28.5$ (3C), 32.9, 79.5, 111.0, 118.7, 122.1 (2C), 126.1, 127.4, 130.1 (2C), 132.0, 133.5, 141.7, 145.2, 153.9, 163.0, 189.7 ppm; MS (EI) calcd for $\mathrm{C}_{20} \mathrm{H}_{23} \mathrm{~N}_{3} \mathrm{O}_{5} \mathrm{~m} / \mathrm{z}$ $[M]^{+}: 385.1638$, found: 385.1632 .

General procedure for the synthesis of the 2'-aminoanilides 9, 11. Example: Synthesis of tert-butyl-(3-(3-(5-((2-aminophenyl)carbamoyl)-1-methyl-1 $H$-pyrrol-3-yl)acryloyl)phenyl)carbamate (9a): $\left(\mathrm{C}_{2} \mathrm{H}_{5}\right)_{3} \mathrm{~N}(1.6 \mathrm{mmol}, 0.22 \mathrm{~mL}$ ) and benzotriazole-1-yloxytris(dimethylamino)phosphonium hexafluorophosphate (BOP reagent) $(0.48 \mathrm{mmol}, 0.21 \mathrm{~g})$ were added to a solution of 4-(3-(3-((tert-butoxycarbonyl)amino)phenyl)-3-oxoprop-1-enyl)-1-methyl-1H-pyrrole-2carboxylic acid 17 a $(0.4 \mathrm{mmol}, 0.32 \mathrm{~g})$ in anhydrous DMF $(5 \mathrm{~mL})$ under $\mathrm{N}_{2}$ atmosphere. The resulting mixture was stirred for $30 \mathrm{~min}$ 
at room temperature; afterward 1,2-phenylenediamine $(0.44 \mathrm{mmol}$, $0.05 \mathrm{~g}$ ) was added under $\mathrm{N}_{2}$ atmosphere and the reaction was stirred overnight. The reaction was quenched with $\mathrm{H}_{2} \mathrm{O}(50 \mathrm{~mL})$ and extracted with EtOAc $(3 \times 30 \mathrm{~mL})$. The combined organic extracts were dried and the residue obtained upon evaporation of solvent was purified by column chromatography $\left(\mathrm{SiO}_{2}\right.$ eluting with EtOAc/n-hexane 1:1) to give pure 9a. ${ }^{1} \mathrm{H} N M R$ ([D $\left.\mathrm{D}_{6}\right] \mathrm{DMSO}$, $400 \mathrm{MHz}): \delta=1.48\left(\mathrm{~s}, 9 \mathrm{H}, \mathrm{C}\left(\mathrm{CH}_{3}\right)_{3}\right), 3.87\left(\mathrm{~s}, 3 \mathrm{H}, \mathrm{CH}_{3}\right), 4.89(\mathrm{bs}, 2 \mathrm{H}$, $\left.\mathrm{NH}_{2}\right)$, 6.59-6.61 $(\mathrm{m}, 1 \mathrm{H}$, benzene proton), 6.75-6.77 $(\mathrm{d}, 1 \mathrm{H}$, benzene proton), 6.96-6.98 $(\mathrm{m}, 1 \mathrm{H}$, benzene proton), 7.14-7.16 $(\mathrm{d}, 1 \mathrm{H}$, benzene proton), 7.26-7.66 $(\mathrm{m}, 7 \mathrm{H}$, benzene protons, pyrrole$\alpha$ and $-\beta$ protons, $\mathrm{PhCOCH}=\mathrm{CH}$ and $\mathrm{PhCOCH}=\mathrm{CH}), 8.09(\mathrm{~s}, 1 \mathrm{H}$, benzene proton), 9.35 (bs, $\left.1 \mathrm{H},\left(\mathrm{CH}_{3}\right)_{3} \mathrm{CONH}\right), 9.52 \mathrm{ppm}(\mathrm{bs}, 1 \mathrm{H}, \mathrm{CONH})$; ${ }^{13} \mathrm{C}$ NMR ([D $]$ DMSO, $\left.400 \mathrm{MHz}\right): \delta=28.5(3 \mathrm{C}), 32.9,79.5,111.0,116.5$, $118.7,119.0,119.6,122.4,122.9,125.2,125.5,126.1,127.4$ (2C), 129.5, 132.0, 136.4, 138.1, 141.8, 145.2, 153.9, 162.7, 189.7 ppm; MS (EI) calcd for $\mathrm{C}_{26} \mathrm{H}_{28} \mathrm{~N}_{4} \mathrm{O}_{4} \mathrm{~m} / z[\mathrm{M}]^{+}: 460.2111$, found: 460.2118 .

tert-Butyl-(4-(3-(5-(hydroxycarbamoyl)-1-methyl-1 H-pyrrol-3-yl)acryloyl)phenyl)carbamate (8b): ${ }^{1} \mathrm{H}$ NMR ([D 6 DMSO, $\left.400 \mathrm{MHz}\right): \delta=$ $1.50\left(\mathrm{~s}, 9 \mathrm{H}, \mathrm{C}\left(\mathrm{CH}_{3}\right)_{3}\right), 3.94\left(\mathrm{~s}, 3 \mathrm{H}, \mathrm{CH}_{3}\right), 7.04(\mathrm{~s}, 1 \mathrm{H}$, pyrrole$\beta$ proton), 7.26-7.67 ( $\mathrm{m}, 6 \mathrm{H}$, benzene protons, $\mathrm{PhCOCH}=\mathrm{CH}$ and $\mathrm{PhCOCH}=\mathrm{CH}$ ), 8.09 (s, $1 \mathrm{H}$, pyrrole- $\alpha$ proton), 8.99 (bs, $1 \mathrm{H}$, $\left.\left(\mathrm{CH}_{3}\right)_{3} \mathrm{CONH}\right), 9.56$ (bs, $\left.1 \mathrm{H}, \mathrm{CONHOH}\right), 10.95 \mathrm{ppm}$ (bs, $1 \mathrm{H}$, $\mathrm{CONHOH}) ;{ }^{13} \mathrm{C}$ NMR ([D 6 DMSO, $\left.400 \mathrm{MHz}\right): \delta=28.5$ (3C), 32.9, 79.5, $111.0,118.7,122.1(2 \mathrm{C}), 126.1,127.4,130.1$ (2C), 132.0, 133.5, 141.7, 145.2, 153.9, 163.0, 189.7 ppm; MS (El) calcd for $\mathrm{C}_{20} \mathrm{H}_{23} \mathrm{~N}_{3} \mathrm{O}_{5} \mathrm{~m} / \mathrm{z}$ $[M]^{+}: 385.1638$, found: 385.1632 .

tert-Butyl-(3-(3-(5-(3-(hydroxyamino)-3-oxoprop-1-enyl)-1methyl-1H-pyrrol-3-yl)acryloyl)phenyl)carbamate (8c): ${ }^{1} \mathrm{H}$ NMR $\left(\left[\mathrm{D}_{6}\right] \mathrm{DMSO}, 400 \mathrm{MHz}\right): \delta=1.50\left(\mathrm{~s}, 9 \mathrm{H}, \mathrm{C}\left(\mathrm{CH}_{3}\right)_{3}\right), 3.94\left(\mathrm{~s}, 3 \mathrm{H}, \mathrm{CH}_{3}\right)$, $7.04(\mathrm{~s}, 1 \mathrm{H}$, pyrrole- $\beta$ proton), 7.26-7.67 ( $\mathrm{m}, 7 \mathrm{H}$, benzene protons, $\mathrm{PhCOCH}=\mathrm{CH}$ and $\mathrm{PhCOCH}=\mathrm{CH}, \mathrm{CH}=\mathrm{CHCONHOH}), 8.09-8.3(\mathrm{~m}, 2 \mathrm{H}$, pyrrole- $\alpha$ proton, $\mathrm{CH}=\mathrm{CHCONHOH}), 8.99\left(\mathrm{bs}, 1 \mathrm{H},\left(\mathrm{CH}_{3}\right)_{3} \mathrm{CONH}\right), 9.56$ (bs, $1 \mathrm{H}, \mathrm{CONHOH}), 10.95 \mathrm{ppm}$ (bs, $1 \mathrm{H}, \mathrm{CONHOH}) ;{ }^{13} \mathrm{C} N M R$ ([D $\left.\left.\mathrm{D}_{6}\right] \mathrm{DMSO}, 400 \mathrm{MHz}\right): \delta=28.5$ (3C), 34.0, 79.5, 104.8, 108.0, 119.6, $123.2,124.9,125.5,127.4$ (2C), 129.5, 130.6, 134.8, 136.4, 138.1, 145.2, 153.9, 161.6, 189.7 ppm; MS (El) calcd for $\mathrm{C}_{22} \mathrm{H}_{25} \mathrm{~N}_{3} \mathrm{O}_{5} \mathrm{~m} / \mathrm{z}$ $[M]^{+}:$411.1794, found: 411.1788 .

tert-Butyl-(4-(3-(5-(3-(hydroxyamino)-3-oxoprop-1-enyl)-1methyl-1 H-pyrrol-3-yl)acryloyl)phenyl)carbamate (8d): ${ }^{1} \mathrm{H}$ NMR ([D $\left.\left.\mathrm{D}_{6}\right] \mathrm{DMSO}, 400 \mathrm{MHz}\right): \delta=1.48\left(\mathrm{~s}, 9 \mathrm{H}, \mathrm{C}\left(\mathrm{CH}_{3}\right)_{3}\right), 3.8\left(\mathrm{~s}, 3 \mathrm{H}, \mathrm{CH}_{3}\right), 6.98$ $(\mathrm{s}, 1 \mathrm{H}$, pyrrole- $\beta$ proton), 7.16-7.7 $(\mathrm{m}, 7 \mathrm{H}$, benzene protons, $\mathrm{PhCOCH}=\mathrm{CH}$ and $\mathrm{PhCOCH}=\mathrm{CH}, \mathrm{CH}=\mathrm{CHCONHOH}), 8.09-8.3(\mathrm{~m}, 2 \mathrm{H}$, pyrrole- $\alpha$ proton, $\mathrm{CH}=\mathrm{CHCONHOH}), 9.02\left(\mathrm{bs}, 1 \mathrm{H},\left(\mathrm{CH}_{3}\right)_{3} \mathrm{CONH}\right), 9.43$ (bs, $1 \mathrm{H}, \mathrm{CONHOH}), 10.97 \mathrm{ppm}$ (bs, $1 \mathrm{H}, \mathrm{CONHOH}) ;{ }^{13} \mathrm{C} \mathrm{NMR}$ ([D $\left.\left.\mathrm{D}_{6}\right] \mathrm{DMSO}, 400 \mathrm{MHz}\right): \delta=28.5(3 \mathrm{C}), 34.0,79.5,104.8,108.0,122.1$ (2C), 123.2, 124.9, 127.4, 130.1 (2C), 130.6, 133.5, 134.8, 141.7, 145.2, 153.9, 161.6, $189.7 \mathrm{ppm}$; MS (El) calcd for $\mathrm{C}_{22} \mathrm{H}_{25} \mathrm{~N}_{3} \mathrm{O}_{5} \mathrm{~m} / \mathrm{z}$ $[M]^{+}$: 411.1794, found: 411.1788 .

tert-Butyl-(3-(3-(4-(hydroxycarbamoyl)phenyl)acryloyl) phenyl)carbamate (10a): ${ }^{1} \mathrm{H} \mathrm{NMR}$ ([D $]$ DMSO, $\left.400 \mathrm{MHz}\right): \delta=1.47(\mathrm{~s}, 9 \mathrm{H}$, $\left.\mathrm{C}\left(\mathrm{CH}_{3}\right)_{3}\right), 7.44-7.48(\mathrm{~m}, 1 \mathrm{H}, \mathrm{COCH}=\mathrm{CH}), 7.50-8.03(\mathrm{~m}, 8 \mathrm{H}$, benzene protons, $\mathrm{PhCOCH}=\mathrm{CH}), 8.10-8.14(\mathrm{~m}, 1 \mathrm{H}$, benzene proton), 9.09 (bs, $\left.1 \mathrm{H},\left(\mathrm{CH}_{3}\right)_{3} \mathrm{CONH}\right), 9.53$ (bs, $\left.1 \mathrm{H}, \mathrm{CONHOH}\right), 11.30 \mathrm{ppm}$ (bs, $1 \mathrm{H}$, CONHOH); ${ }^{13} \mathrm{C}$ NMR ([D 6 DMSO, $\left.400 \mathrm{MHz}\right): \delta=28.5(3 \mathrm{C}), 79.5,119.6$, $121.4,125.5,126.5$ (2C), $127.4(3 \mathrm{C}), 129.5,133.4,136.4,138.1,138.6$, 145.2, 153.9, 163.0, $189.7 \mathrm{ppm}$; MS (El) calcd for $\mathrm{C}_{21} \mathrm{H}_{22} \mathrm{~N}_{2} \mathrm{O}_{5} \mathrm{~m} / \mathrm{z}$ $[M]^{+}:$382.1529, found: 382.1535 .

tert-Butyl-(4-(3-(4-(hydroxycarbamoyl)phenyl)acryloyl) phenyl)carbamate (10 b): ${ }^{1} \mathrm{H}$ NMR ([D 6 DMSO, $\left.400 \mathrm{MHz}\right): \delta=1.49(\mathrm{~s}, 9 \mathrm{H}$, $\left.\mathrm{C}\left(\mathrm{CH}_{3}\right)_{3}\right), 6.65-8.11(\mathrm{~m}, 10 \mathrm{H}$, benzene protons, $\mathrm{PhCOCH}=\mathrm{CH}$ and
$\mathrm{COCH}=\mathrm{CH}), 9.10\left(\mathrm{bs}, 1 \mathrm{H},\left(\mathrm{CH}_{3}\right)_{3} \mathrm{CONH}\right), 9.84$ (bs, $\left.1 \mathrm{H}, \mathrm{CONHOH}\right)$, $11.39 \mathrm{ppm}$ (bs, $1 \mathrm{H}, \mathrm{CONHOH}) ;{ }^{13} \mathrm{C}$ NMR ([D $]$ DMSO, $\left.400 \mathrm{MHz}\right): \delta=$ $28.5(3 \mathrm{C}), 79.5,121.4,122.1(2 \mathrm{C}), 126.5(2 \mathrm{C}), 127.4(2 \mathrm{C}), 130.1(2 \mathrm{C})$, 133.4, 133.5, 138.6, 141.7, 145.2, 153.9, 163.0, 189.7 ppm; MS (EI) calcd for $\mathrm{C}_{21} \mathrm{H}_{22} \mathrm{~N}_{2} \mathrm{O}_{5} \mathrm{~m} / \mathrm{z}[\mathrm{M}]^{+}: 382.1529$, found: 382.1535 .

tert-Butyl-(3-(3-(4-(3-(hydroxyamino)-3-oxoprop-1-enyl) phenyl)acryloyl)phenyl)carbamate $(10 \mathrm{c})$ : ${ }^{1} \mathrm{H}$ NMR ([D 6 DMSO, $\left.400 \mathrm{MHz}\right)$ : $\delta=1.48\left(\mathrm{~s}, 9 \mathrm{H}, \mathrm{C}\left(\mathrm{CH}_{3}\right)_{3}\right), 6.52-6.56(\mathrm{~d}, 1 \mathrm{H}, \mathrm{CH}=\mathrm{CHCONH}), 7.47-7.50$ $(\mathrm{d}, 1 \mathrm{H}, \mathrm{PhCOCH}=\mathrm{CH}), 7.63-7.96(\mathrm{~m}, 10 \mathrm{H}$, benzene protons, $\mathrm{CH}=$ $\mathrm{CHCONH}$ and $\mathrm{PhCOCH}=\mathrm{CH}), 9.12\left(\mathrm{bs}, 1 \mathrm{H},\left(\mathrm{CH}_{3}\right)_{3} \mathrm{CONH}\right), 9.55$ (bs, $1 \mathrm{H}, \mathrm{CONHOH}), 10.79 \mathrm{ppm}$ (bs, $1 \mathrm{H}, \mathrm{CONHOH}) ;{ }^{13} \mathrm{C}$ NMR ([D $\mathrm{D}_{6} \mathrm{DMSO}$, $400 \mathrm{MHz}$ ): $\delta=28.5$ (3C), 79.5, 118.9, 119.6, 121.4, 125.5, 126.3 (4C), 127.4, 129.5, 134.4 (2C), 136.4, 138.1, 144.0, 145.2, 153.9, 161.6, 189.7 ppm; MS (El) calcd for $\mathrm{C}_{23} \mathrm{H}_{24} \mathrm{~N}_{2} \mathrm{O}_{5} \mathrm{~m} / \mathrm{z}[\mathrm{M}]^{+}: 408.1685$, found: 408.1691.

tert-Butyl-(4-(3-(4-(3-(hydroxyamino)-3-oxoprop-1-enyl)phenyl)acryloyl)phenyl)carbamate (10 d): ${ }^{1} \mathrm{H}$ NMR ([D 6$]$ DMSO, $\left.400 \mathrm{MHz}\right)$ : $\delta=1.47\left(\mathrm{~s}, 9 \mathrm{H}, \mathrm{C}\left(\mathrm{CH}_{3}\right)_{3}\right), 6.52-6.55(\mathrm{~d}, 1 \mathrm{H}, \mathrm{CH}=\mathrm{CHCONH}), 7.45-7.47$ (d, $1 \mathrm{H}, \mathrm{PhCOCH}=\mathrm{CH}), 7.49-8.09(\mathrm{~m}, 10 \mathrm{H}$, benzene protons, $\mathrm{CH}=$ $\mathrm{CHCONH}$ and $\mathrm{PhCOCH}=\mathrm{CH}$ ), 9.10 (bs, $\left.1 \mathrm{H},\left(\mathrm{CH}_{3}\right)_{3} \mathrm{CONH}\right), 9.80$ (bs, $1 \mathrm{H}, \mathrm{CONHOH}), 10.78 \mathrm{ppm}(\mathrm{bs}, 1 \mathrm{H}, \mathrm{CONHOH}) ; \mathrm{C}^{13} \mathrm{NMR}\left(\left[\mathrm{D}_{6}\right] \mathrm{DMSO}\right.$, $400 \mathrm{MHz}): \delta=28.5$ (3C), 79.5, 118.9, 121.4, 122.1 (2C), 126.3 (4C), 130.1 (2C), 133.5, 134.4 (2C), 141.7, 144.0, 145.2, 153.9, 161.6, 189.7 ppm; MS (EI) calcd for $\mathrm{C}_{23} \mathrm{H}_{24} \mathrm{~N}_{2} \mathrm{O}_{5} \mathrm{~m} / z[M]^{+}: 408.1685$, found: 408.1691.

tert-Butyl-(4-(3-(5-((2-aminophenyl)carbamoyl)-1-methyl-1 Hpyrrol-3-yl)acryloyl)phenyl)carbamate (9b): ${ }^{1} \mathrm{H}$ NMR ([D $\mathrm{D}_{6} \mathrm{DMSO}$, $400 \mathrm{MHz}): \delta=1.49\left(\mathrm{~s}, 9 \mathrm{H}, \mathrm{C}\left(\mathrm{CH}_{3}\right)_{3}\right), 3.91\left(\mathrm{~s}, 3 \mathrm{H}, \mathrm{CH}_{3}\right), 4.89$ (bs, $2 \mathrm{H}$, $\left.\mathrm{NH}_{2}\right), 6.49-6.51(\mathrm{~m}, 1 \mathrm{H}$, benzene proton), 6.56-6.63 $(\mathrm{d}, 1 \mathrm{H}$, benzene proton), $6.75-6.81(\mathrm{~m}, 1 \mathrm{H}$, benzene proton), $6.92-6.94(\mathrm{~d}, 1 \mathrm{H}$, benzene proton), 7.31-7.64 (m, 7H, benzene protons, pyrrole$\alpha$ and $-\beta$ protons, $\mathrm{PhCOCH}=\mathrm{CH}$ and $\mathrm{PhCOCH}=\mathrm{CH}$ ), 8.08-8.09 (d, $1 \mathrm{H}$, benzene proton), 9.35 (bs, $\left.1 \mathrm{H},\left(\mathrm{CH}_{3}\right)_{3} \mathrm{CONH}\right), 9.52 \mathrm{ppm}(\mathrm{bs}, 1 \mathrm{H}$, CONH); ${ }^{13} \mathrm{C}$ NMR ([D $\left.\left.\mathrm{D}_{6}\right] \mathrm{DMSO}, 400 \mathrm{MHz}\right): \delta=28.5$ (3C), 32.9, 79.5, $111.0,116.5,118.7,119.0,122.1$ (2C), 122.4, 122.9, 125.2, 126.1, 127.4, 130.1 (2C), 132.0, 133.5, 141.7, 141.8, 145.2, 153.9, 162.7, 189.7 ppm; MS (El) calcd for $\mathrm{C}_{26} \mathrm{H}_{28} \mathrm{~N}_{4} \mathrm{O}_{4} \mathrm{~m} / z[M]^{+}: 460.2111$, found: 460.2118.

tert-Butyl-(3-(3-(5-(3-(2-aminophenylamino)-3-oxoprop-1-enyl)-1methyl-1H-pyrrol-3-yl)acryloyl)phenyl)carbamate (9c): ${ }^{1} \mathrm{H}$ NMR ([D $\left.\left.\mathrm{D}_{6}\right] \mathrm{DMSO}, 400 \mathrm{MHz}\right): \delta=1.48\left(\mathrm{~s}, 9 \mathrm{H}, \mathrm{C}\left(\mathrm{CH}_{3}\right)_{3}\right), 3.79\left(\mathrm{~s}, 3 \mathrm{H}, \mathrm{CH}_{3}\right)$, 4.89 (bs, $\left.2 \mathrm{H}, \mathrm{NH}_{2}\right), 6.57-6.59(\mathrm{~m}, 1 \mathrm{H}$, benzene proton), 6.72-6.75 (d, $3 \mathrm{H}, \mathrm{CH}=\mathrm{CHCONH}$, benzene protons), $6.88-6.90(\mathrm{~m}, 1 \mathrm{H}$, benzene proton), $7.15(\mathrm{~s}, 1 \mathrm{H}$, pyrrole- $\alpha$ proton), $7.33-7.35(\mathrm{~m}, 1 \mathrm{H}$, benzene proton) $7.42-7.72(\mathrm{~m}, 6 \mathrm{H}$, benzene protons, pyrrole- $\beta$ proton, $\mathrm{CH}=$ $\mathrm{CHCONH}, \quad \mathrm{PhCOCH}=\mathrm{CH}, \quad \mathrm{PhCOCH}=\mathrm{CH}), 8.12(\mathrm{~s}, 1 \mathrm{H}$, benzene proton), 9.34 (bs, $\left.1 \mathrm{H},\left(\mathrm{CH}_{3}\right)_{3} \mathrm{CONH}\right), 9.52 \mathrm{ppm}$ (bs, $\left.1 \mathrm{H}, \mathrm{CONH}\right)$; ${ }^{13} \mathrm{C}$ NMR ([D $\left.] \mathrm{DMSO}, 400 \mathrm{MHz}\right): \delta=28.5$ (3C), 34.0, 79.5, 104.8, $108.0,116.5,119.0,119.6,122.4,122.9,123.2,124.9,125.2,125.5$, 127.4 (2C), 129.5, 130.6, 134.8, 136.4, 138.1, 141.8, 145.2, 153.9, 166.7, 189.7 ppm; MS (El) calcd for $\mathrm{C}_{28} \mathrm{H}_{30} \mathrm{~N}_{4} \mathrm{O}_{4} \mathrm{~m} / \mathrm{z}[\mathrm{M}]^{+}$: 486.2267, found: 486.2261 .

tert-Butyl-(4-(3-(5-(3-(2-aminophenylamino)-3-oxoprop-1-enyl)-1methyl-1 H-pyrrol-3-yl)acryloyl)phenyl)carbamate (9d): ${ }^{1} \mathrm{H}$ NMR ([D $\left.\left.\mathrm{D}_{6}\right] \mathrm{DMSO}, 400 \mathrm{MHz}\right): \delta=1.49\left(\mathrm{~s}, 9 \mathrm{H}, \mathrm{C}\left(\mathrm{CH}_{3}\right)_{3}\right), 3.78\left(\mathrm{~s}, 3 \mathrm{H}, \mathrm{CH}_{3}\right)$, 4.93 (bs, $\left.2 \mathrm{H}, \mathrm{NH}_{2}\right), 6.55-6.59(\mathrm{~m}, 1 \mathrm{H}$, benzene proton), 6.71-6.75 $(\mathrm{d}, 3 \mathrm{H}, \mathrm{CH}=\mathrm{CHCONH}$, benzene protons), $6.88-6.91(\mathrm{~m}, 1 \mathrm{H}$, benzene proton), $7.17(\mathrm{~s}, 1 \mathrm{H}$, pyrrole- $\alpha$ proton), $7.34-7.36(\mathrm{~m}, 1 \mathrm{H}$, benzene proton) $7.52-7.74(\mathrm{~m}, 5 \mathrm{H}$, benzene proton, pyrrole- $\beta$ proton, $\mathrm{CH}=$ $\mathrm{CHCONH}, \mathrm{PhCOCH}=\mathrm{CH}, \mathrm{PhCOCH}=\mathrm{CH}), 8.04-8.06(\mathrm{~d}, 2 \mathrm{H}$, benzene protons), 9.34 (bs, $\left.1 \mathrm{H},\left(\mathrm{CH}_{3}\right)_{3} \mathrm{CONH}\right), 9.52 \mathrm{ppm}$ (bs, $\left.1 \mathrm{H}, \mathrm{CONH}\right)$; 
${ }^{13} \mathrm{C}$ NMR ([D 6 DMSO, $\left.400 \mathrm{MHz}\right): \delta=28.5$ (3C), 34.0, 79.5, 104.8, $108.0,116.5,119.0,122.1$ (2C), 122.4, 122.9, 123.2, 124.9, 125.2, $127.4,130.1$ (2C), 130.6, 133.5, 134.8, 141.7, 141.8, 145.2, 153.9, 166.7, 189.7 ppm; MS (El) calcd for $\mathrm{C}_{28} \mathrm{H}_{30} \mathrm{~N}_{4} \mathrm{O}_{4} \mathrm{~m} / \mathrm{z}[\mathrm{M}]^{+}:$: 486.2267, found: 486.2261

tert-Butyl-(3-(3-(4-((2-aminophenyl)carbamoyl)phenyl) acryloyl)phenyl)carbamate (11 a): ${ }^{1} \mathrm{H}$ NMR ([D $\left.\mathrm{D}_{6} \mathrm{DMSO}, 400 \mathrm{MHz}\right): \delta=1.49(\mathrm{~s}$, $\left.9 \mathrm{H}, \mathrm{C}\left(\mathrm{CH}_{3}\right)_{3}\right), 4.93$ (bs, $\left.2 \mathrm{H}, \mathrm{NH}_{2}\right), 6.58-6.61(\mathrm{~m}, 1 \mathrm{H}$, benzene proton), 6.77-6.79 $(\mathrm{d}, 1 \mathrm{H}$, benzene proton), 6.96-6.99 $(\mathrm{m}, 1 \mathrm{H}$, benzene proton), 7.16-7.18 $(\mathrm{d}, 1 \mathrm{H}$, benzene proton), 7.63-7.65 $(\mathrm{d}, 2 \mathrm{H}$, benzene protons), 7.69-7.74 (d, $1 \mathrm{H}, \mathrm{PhCOCH}=\mathrm{CH}), 7.96-8.23(\mathrm{~m}, 5 \mathrm{H}$, benzene protons and $\mathrm{PhCOCH}=\mathrm{CH}), 8.15-8.23(\mathrm{~d}, 2 \mathrm{H}$, benzene protons), 9.75 (bs, $\left.1 \mathrm{H},\left(\mathrm{CH}_{3}\right)_{3} \mathrm{CONH}\right), 9.83 \mathrm{ppm}$ (bs, $\left.1 \mathrm{H}, \mathrm{CONH}\right)$; ${ }^{13} \mathrm{C}$ NMR ([D $]$ DMSO, $\left.400 \mathrm{MHz}\right): \delta=28.5$ (3C), 79.5, 116.5, 119.0, 119.6, 121.4, 122.4, 122.9, 125.2, 125.5, 126.5 (2C), 127.4 (3C), 129.5, 133.4, 136.4, 138.1, 138.6, 141.8, 145.2, 153.9, 164.8, 189.7 ppm; MS (EI) calcd for $\mathrm{C}_{27} \mathrm{H}_{27} \mathrm{~N}_{3} \mathrm{O}_{4} \mathrm{~m} / \mathrm{z}[\mathrm{M}]^{+}: 457.2002$, found: 457.2008 .

tert-Butyl-(4-(3-(4-((2-aminophenyl)carbamoyl)phenyl) acryloyl)phenyl)carbamate (11 b): ${ }^{1} \mathrm{H}$ NMR ([D $]$ DMSO, $\left.400 \mathrm{MHz}\right): \delta=1.49$ (s, $\left.9 \mathrm{H}, \mathrm{C}\left(\mathrm{CH}_{3}\right)_{3}\right), 4.93\left(\mathrm{bs}, 2 \mathrm{H}, \mathrm{NH}_{2}\right), 6.58-6.61(\mathrm{~m}, 1 \mathrm{H}$, benzene proton), 6.77-6.79 $(\mathrm{m}, 1 \mathrm{H}$, benzene proton), 6.96-6.99 $(\mathrm{m}, 1 \mathrm{H}$, benzene proton), 7.16-7.18 $(\mathrm{m}, 1 \mathrm{H}$, benzene proton), 7.63-7.65 (d, $2 \mathrm{H}$, benzene protons), 7.69-7.74 (d, $1 \mathrm{H}, \mathrm{PhCOCH}=\mathrm{CH}), 7.96-8.23(\mathrm{~m}, 5 \mathrm{H}$, benzene protons and $\mathrm{PhCOCH}=\mathrm{CH}), 8.15-8.23(\mathrm{~d}, 2 \mathrm{H}$, benzene protons), 9.75 (bs, $\left.1 \mathrm{H},\left(\mathrm{CH}_{3}\right)_{3} \mathrm{CONH}\right), 9.83 \mathrm{ppm}$ (bs, $\left.1 \mathrm{H}, \mathrm{CONH}\right)$; ${ }^{13} \mathrm{C}$ NMR ([D $\left.\left.\mathrm{D}_{6}\right] \mathrm{DMSO}, 400 \mathrm{MHz}\right): \delta=28.5$ (3C), 79.5, 116.5, 119.0, $121.4,122.1(2 \mathrm{C}), 122.4,122.9,125.2,126.5(2 \mathrm{C}), 127.4(2 \mathrm{C}), 130.1$ (2C), 133.4, 133.5, 138.6, 141.7, 141.8, 145.2, 153.9, 164.8, $189.7 \mathrm{ppm}$; MS (El) calcd for $\mathrm{C}_{27} \mathrm{H}_{27} \mathrm{~N}_{3} \mathrm{O}_{4} \mathrm{~m} / z[\mathrm{M}]^{+}: 457.2002$, found: 457.2008

tert-Butyl-(3-(3-(4-(3-(2-aminophenylamino)-3-oxoprop-1-enyl)phenyl)acryloyl)phenyl)carbamate (11 c): ${ }^{1} \mathrm{H}$ NMR ([D $\left.\mathrm{D}_{6}\right] \mathrm{DMSO}$, $400 \mathrm{MHz}): \delta=1.49\left(\mathrm{~s}, 9 \mathrm{H}, \mathrm{C}\left(\mathrm{CH}_{3}\right)_{3}\right), 4.95\left(\mathrm{bs}, 2 \mathrm{H}, \mathrm{NH}_{2}\right), 6.59-6.63(\mathrm{~m}$ $1 \mathrm{H}$, benzene proton), 6.73-6.75 $(\mathrm{m}, 1 \mathrm{H}$, benzene proton), $6.83-$ $6.85(\mathrm{~d}, 1 \mathrm{H}, \mathrm{PhCOCH}=\mathrm{CH}), 6.97-6.99(\mathrm{~m}, 1 \mathrm{H}$, benzene proton $)$, 7.18-7.20 $(\mathrm{m}, 1 \mathrm{H}$, benzene proton $), 7.33-7.35(\mathrm{~d}, 1 \mathrm{H}, \mathrm{PhCOCH}=$ $\mathrm{CH}), 7.44-7.47(\mathrm{t}, 1 \mathrm{H}$, benzene proton), 7.73-8.19 $(\mathrm{m}, 8 \mathrm{H}$, benzene protons, $\mathrm{PhCOCH}=\mathrm{CH}$ and $\mathrm{PhCOCH}=\mathrm{CH}), 8.30-8.31(\mathrm{~m}, 1 \mathrm{H}$ benzene proton), 9.57 (bs, $\left.1 \mathrm{H},\left(\mathrm{CH}_{3}\right)_{3} \mathrm{CONH}\right), 9.75 \mathrm{ppm}$ (bs, $\left.1 \mathrm{H}, \mathrm{CONH}\right)$; ${ }^{13} \mathrm{C}$ NMR ([D $]$ DMSO, $\left.400 \mathrm{MHz}\right): \delta=28.5$ (3C), 79.5, 116.5, 118.9, $119.0,119.6,121.4,122.4,122.9,125.2,125.5,126.3$ (4C), 127.4, 129.5, 134.4 (2C), 136.4, 138.1, 141.8, 144.0, 145.2, 153.9, 166.7, 189.7 ppm; MS (El) calcd for $\mathrm{C}_{29} \mathrm{H}_{29} \mathrm{~N}_{3} \mathrm{O}_{4} \mathrm{~m} / z[\mathrm{M}]^{+}: 483.2158$, found: 483.2165 .

tert-Butyl-(4-(3-(4-(3-(2-aminophenylamino)-3-oxoprop-1-enyl)phenyl)acryloyl)phenyl)carbamate (11 d): ${ }^{1} \mathrm{H}$ NMR ([D 6 DMSO, $400 \mathrm{MHz}): \delta=1.47\left(\mathrm{~s}, 9 \mathrm{H}, \mathrm{C}\left(\mathrm{CH}_{3}\right)_{3}\right), 4.55$ (bs, 2H, NH$)_{2}, 6.56-6.91(\mathrm{~m}$, $5 \mathrm{H}, \mathrm{CH}=\mathrm{CHCONH}$, benzene protons $), 7.33-8.10(\mathrm{~m}, 11 \mathrm{H}, \mathrm{PhCOCH}=$ $\mathrm{CH}, \mathrm{CH}=\mathrm{CHCONH}, \mathrm{PhCOCH}=\mathrm{CH}$ and benzene protons), 9.30 (bs, $\left.1 \mathrm{H},\left(\mathrm{CH}_{3}\right)_{3} \mathrm{CONH}\right), 9.80 \mathrm{ppm}(\mathrm{bs}, 1 \mathrm{H}, \mathrm{CONH}) ;{ }^{13} \mathrm{C} \mathrm{NMR}\left(\left[\mathrm{D}_{6}\right] \mathrm{DMSO}\right.$, $400 \mathrm{MHz}): \delta=28.5(3 \mathrm{C}), 79.5,116.5,118.9,119.0,121.4,122.1$ (2C), $122.4,122.9,125.2,126.3(4 \mathrm{C}), 130.1$ (2C), 133.5, $134.4(2 \mathrm{C}), 141.7$, $141.8,144.0,145.2,153.9,166.7,189.7$ ppm; MS (El) calcd for $\mathrm{C}_{29} \mathrm{H}_{29} \mathrm{~N}_{3} \mathrm{O}_{4} \mathrm{~m} / \mathrm{z}[\mathrm{M}]^{+}:$: 483.2158, found: 483.2165 .

Fluorimetric hrHDAC1 and hrHDAC4 assays: The HDAC Fluorescent Activity Assay for HDAC1 and HDAC4 is based on the Fluor de Lys Substrate and Developer combination (BioMol), and has been carried out according to the supplier's instructions and as previously reported ${ }^{[8 \mathrm{~d}]}$ First, the inhibitors and purified recombinant HDAC1 or HDAC4 enzymes have been pre-incubated at room temperature for $15 \mathrm{~min}$ before the addition of the substrate which is the Fluor de Lys substrate, which comprises an acetylated lysine side chain. For the HDAC4 assay, the HDAC4-selective, non-histone substrate reported by Lahm et al. ${ }^{[13]}$ was used. Full-length HDAC1 and HDAC4 with C-terminal His tags were expressed using baculovirus systems. Deacetylation sensitizes the substrates that, in the second step, treated with the developer produce a fluorophore. Fluorescence was with a TECAN Infinite M200 station.

Molecular modeling studies: The human HDAC6 homology model was obtained using the I-TASSER approach (http://zhanglab.ccmb. med.umich.edu/l-TASSER/ [accessed February 27, 2013]). In particular the sequence of the second catalytic subunit of HDAC6 (Q9UBN7), retrieved from the Uniprot server (http://www.uniprot. org [accessed February 27, 2013]), was used as the input for the ITASSER method. The position of the zinc ion and the conformation of the chelating residues were extracted from the resolved structure of human HDAC7 complexed with SAHA (PDB ID: 3COZ). ${ }^{[21]}$ The constructed model was then processed using the Protein Preparation Wizard panel of the Schrödinger 2012 molecular modeling package (Schrödinger Suite 2012, Schrödinger LLC, New York, NY, USA). In particular, using the preprocess and analyze structure tool, the bond orders were assigned, all the hydrogen atoms were added, and the disulfide bonds were assigned. Using Epik 2.0 a prediction of the heterogroups ionization and tautomeric states was performed. An optimization of the hydrogen bonding network was performed using the $\mathrm{H}$-bond assignment tool. Finally, using the impref utility, the positions of the hydrogen atoms were optimized by keeping all the heavy atoms in place.

Ligand files (10c and $\mathbf{1 0 d}$ ) were prepared employing the Builder tool and generated with the Ligprep module within Schrödinger 2012 molecular modeling package (Schrödinger Suite 2012, Schrödinger LLC, New York, NY, USA). Partial ligand charges were calculated by means of the Jaguar suite (Jaguar 4.1; Schrödinger, Inc., Portland, OR, USA) within the same package. The electrostatic potential was computed using $6-31 \mathrm{G}^{*}$ basis set.

Ligands were submitted as starting geometries to IFD calculations (Schrödinger Suite 2012, Schrödinger LLC, New York, NY, USA) using Glide (Glide 5.7; Schrödinger Suite 2012, Schrödinger LLC, New York, NY, USA) In the first IFD stage, a softened-potential docking was performed using GlideSP (Standard Precision) mode generating 20 initial poses. For each one, a full circle of protein refinement was performed using Prime (Prime 3.0; Schrödinger Suite 2011, Schrödinger LLC, New York, NY, USA). Residues of the protein within $5.0 \AA$ of ligand poses were refined, and side chains were conformationally changed and subsequently minimized. Ligands were re-docked with GlideXP included in IFD to generate poses. All ligand-protein complex pictures were rendered employing the UCSF Chimera software. ${ }^{[22]}$

Cell cultures: U937 human acute leukemia cells were cultured in RPMI with $10 \%$ fetal calf serum, $100 \mathrm{U} \mathrm{mL}^{-1}$ penicillin, $100 \mu \mathrm{g} \mathrm{mL}^{-1}$ streptomycin, $250 \mathrm{ng} \mathrm{mL}^{-1}$ amphotericin-B, $10 \mathrm{mM}$ HEPES, and $2 \mathrm{~mm}$ glutamine. U937 cells were kept at a constant concentration of 200000 cells per mL culture medium. HT29 (colon carcinoma cancer), M14 (melanoma), H1299 (non-small-cell lung adenocarcinoma), MCF7 (breast adenocarcinoma), HEY (ovarian carcinoma), U87 (glioblastoma), LAN-5 (neuroblastoma), SH-SY5Y (neuroblastoma), PANC-1 (pancreatic carcinoma), PC3 (prostate carcinoma), SKOV3 (ovarian carcinoma), K562 (chronic myeloid leukemia), A549 (non-small-cell lung adenocarcinoma), and HCT116 (colon carcinoma) cells were cultured in RPMI (Invitrogen, Carlsbad, CA, USA) with $10 \%$ fetal calf serum (HyClone, Thermo Scientific, South Logan, UT, USA), and $100 \mathrm{U} \mathrm{mL}^{-1}$ penicillin. 
Western blot analysis for $\alpha$-tubulin and histone $\mathrm{H} 3$ acetylation: For determination of the acetylation levels of $\alpha$-tubulin in U937 cells and histone H3 in HT29 cells, $25 \mu \mathrm{g}$ of total protein extracted from the cells were separated on 10 and $13.5 \%$ polyacrylamide gels, respectively, and blotted as previously described. ${ }^{[18,23]}$ Immunodetection was performed using antibodies directed to acetylated $\alpha$-tubulin (Sigma-Aldrich, St. Louis, MO, USA), total ERKs (Santa Cruz Biotechnology, Santa Cruz, CA, USA), acetyl (Lys 9/14)-histone H3 (Ac-H3, Millipore, Billerica, MA, USA), and $\beta$-actin (Sigma-Aldrich). Anti-mouse or anti-rabbit immunoglobulin G (IgG)-horseradish peroxidase (HRP)-conjugated antibodies (Amersham Biosciences, Freiburg, Germany) were used as secondary antibodies at 1:10000 dilution. Antibody binding was visualized by enhanced chemiluminescence according to manufacturer's specification and recorded on autoradiography film (Amersham Biosciences).

HDAC1-11 isoforms inhibition assay: Individual $I_{50}$ values for each HDAC isozyme were measured with the homogeneous fluorescence release HDAC assay. Purified recombinant enzymes were incubated with serial diluted inhibitors at the indicated concentration. The deacetylase activities of HDACs $1,2,3,6$, and 10 were measured by assaying enzyme activity using AMC-K(AC)GL substrate and AMC-K(TFA)GL substrate for HDACs 4, 5, 7, 8, 9, and 11 as previously described. ${ }^{[13,24]}$ Deacetylated AMC-KGL was sensitive toward lysine peptidase, and free fluorogenic 4-methylcoumarin-7amide (MCA) was generated, which can be excited at $355 \mathrm{~nm}$ and observed at $460 \mathrm{~nm}$. The data was analyzed on a plate to plate basis in relationship to the control and imported into analytical software (GraphPad Prism).

Cell-cycle analysis of U937 cells: $2.5 \times 10^{5}$ treated and untreated cells were collected, fixed, and resuspended in $500 \mu \mathrm{L}$ of a hypotonic buffer $\left(0.1 \%\right.$ Triton $\mathrm{X}-100,0.1 \%$ sodium citrate, $50 \mu \mathrm{g} \mathrm{mL}^{-1}$ propidium iodide (PI), RNase A). Cells were incubated in the dark for $30 \mathrm{~min}$. Samples were acquired on a FACS-Calibur flow cytometer using Cell Quest software (Becton Dickinson, Franklin Lakes, NJ, USA) and analyzed with standard procedures using Cell Quest software (Becton Dickinson) and ModFit LT version 3 Software (Verity) as previously reported. ${ }^{[18]}$ All the experiments were performed three times.

Granulocytic differentiation on U937 cells: Granulocytic differentiation of U937 cells was carried out as previously described. ${ }^{[25]}$ Briefly, treated and untreated cells were harvested and resuspended in $10 \mu \mathrm{L}$ phycoerythrin-conjugated CD11c (CD11c-PE). Control samples were incubated with $10 \mu \mathrm{L}$ PE-conjugated mouse IgG1, incubated for $30 \mathrm{~min}$ at $4{ }^{\circ} \mathrm{C}$ in the dark, washed in PBS, and resuspended in $500 \mu \mathrm{L}$ PBS containing PI $\left(0.25 \mu \mathrm{g} \mathrm{mL}^{-1}\right)$. Samples were analyzed by FACS with Cell Quest technology (Becton Dickinson). $\mathrm{PI}+$ cells were excluded from the analysis.

Antiproliferative effects of compounds 8 and 10 on a wide panel of cancer cell lines: The antiproliferative effect of selected 8 and 10 compounds was evaluated against K562, A549, and HCT116 cell lines using the CellTiter-Glo luminescent cell viability assay (Promega, Madison, WI, USA) according to the manufacturer's instructions. K562, A549, and HCT116 cells were incubated for $72 \mathrm{~h}$ with various inhibitor concentrations. An equivalent of the CellTiter-Glo reagent was then added, the solution was mixed for 2 min in order to induce cell lysis, and the luminescence was recorded after a further $10 \mathrm{~min}$. $I C_{50}$ values were calculated using GraphPad software.

The antiproliferative effect of $10 \mathrm{c}$ on a wider panel of cancer cell lines was evaluated by 3-(4,5-dimethylthiazol-2-yl)-2,5-diphenyltetrazolium bromide (MTT, mitochondrial respiration analysis, Sigma-
Aldrich). Briefly, exponentially growing tumor cells were seeded $\left(3 \times 10^{3}\right.$ cells per well) in sextuplicate in 96-well culture plates (Nunc, Milan, Italy), and $24 \mathrm{~h}$ later cells were treated with $10 \mathrm{c}$ at concentrations ranging from 0.1 to $100 \mu \mathrm{M}$ for 24 or $48 \mathrm{~h}$. Cells were also treated with $1 \%$ DMSO, as control. Recovery experiments were performed by treating cells for $24 \mathrm{~h}$ with the compound and assessing cell proliferation both at the end of treatment and from 24 to $96 \mathrm{~h}$ after the washout of the drug. Cell viability was evaluated by adding $\mathrm{MTT}$ to each well at a final concentration of $0.5 \mathrm{mg} \mathrm{mL}^{-1}$ and after $4 \mathrm{~h}$ of incubation at $37^{\circ} \mathrm{C}$, the formazan salt was dissolved with $200 \mu \mathrm{L}$ isopropyl alcohol. The absorbance of each well was measured with an ELISA reader (DASIT, Milan, Italy) at $\lambda 570 \mathrm{~nm}$ and the viability was calculated for each concentration of $10 \mathrm{c}$ used as $\left(\mathrm{OD}_{\text {treated cells }}\right) /\left(\mathrm{OD}_{\text {control cells }}\right) \times 100$. The concentration of $10 \mathrm{c}$ that causes a $50 \%$ of cell viability inhibition $\left(\mathrm{IC}_{50}\right)$ was also calculated.

In vitro colony-forming assay: Suspensions from treated (0.5$5 \mu \mathrm{M} \mathrm{10c,} 24 \mathrm{~h}$ ) and untreated HT29 cells were seeded into $60 \mathrm{~mm}$ Petri dishes (Nunc, Mascia Brunelli, Milano, Italy) for 10 days. Colonies were stained with $2 \%$ methylene blue in $95 \%$ ethanol and counted ( 1 colony $>50$ cells). The surviving fractions were calculated as the ratio of number of colonies per number of plated cells $\times 100$.

\section{Acknowledgements}

This work was supported by PRIN 2009PX2T2E, FIRB RBFR10ZJQT, EPIGEN (MIUR-CNR), the Italian Association for Cancer Research (AIRC no. 11812 and MFAG no. 11502), and FP7 Project BLUEPRINT/282510.

Keywords: anilides · apoptosis $\cdot$ hydroxamates $\cdot$ pyrroles $\cdot$ tertbutylcarbamates

[1] A. L. Clayton, C. A. Hazzalin, L. C. Mahadevan, Mol. Cell 2006, 23, 289296.

[2] a) X. J. Yang, E. Seto, Nat. Rev. Mol. Cell Biol. 2008, 9, 206-218; b) M. Haberland, R. L. Montgomery, E. N. Olson, Nat. Rev. Genet. 2009, 10, $32-$ 42.

[3] a) A. Mai, Epigenomics 2010, 2, 307-324; b) M. Conte, L. Altucci, Clin. Cancer Res. 2012, 18, 5526-5534; c) W. Weichert, A. Roske, S. Niesporek, A. Noske, A. C. Buckendahl, M. Dietel, V. Gekeler, M. Boehm, T. Beckers, C. Denkert, Clin. Cancer Res. 2008, 14, 1669-1677; d) W. Weichert, Cancer Lett. 2009, 280, 168-176; e) Z. Zhang, H. Yamashita, T. Toyama, H. Sugiura, Y. Ando, K. Mita, M. Hamaguchi, Y. Hara, S. Kobayashi, H. Iwase, Breast Cancer Res. Treat. 2005, 94, 11-16; f) T. Rikimaru, A. Taketo$\mathrm{mi}$, Y. Yamashita, K. Shirabe, T. Hamatsu, M. Shimada, Y. Maehara, Oncology 2007, 72, 69-74; g) F. R. Fritzsche, W. Weichert, A. Roske, V. Gekeler, T. Beckers, C. Stephan, K. Jung, K. Scholman, C. Denkert, M. Dietel, G. Kristiansen, BMC Cancer 2008, 8, 381; h) K. Miyake, T. Yoshizumi, S. Imura, K. Sugimoto, E. Batmunkh, H. Kanemura, Y. Morine, M. Shimada, Pancreas 2008, 36, e1-9; i) W. Weichert, A. Roske, V. Gekeler, T. Beckers, C. Stephan, K. Jung, F. R. Fritzsche, S. Niesporek, C. Denkert, M. Dietel, G. Kristiansen, Br. J. Cancer 2008, 98, 604-610; j) H. H. Chang, C. P. Chiang, H. C. Hung, C. Y. Lin, Y. T. Deng, M. Y. Kuo, Oral Oncol. 2009, 45, 610-614.

[4] S. Spiegel, S. Milstien, S. Grant, Oncogene 2012, 31, 537-551.

[5] a) P. A. Marks, R. Breslow, Nat. Biotechnol. 2007, 25, 84-90; b) C. Campas-Moya, Drugs Today 2009, 45, 787-795; c) S. J. Harrison, M. Bishton, S. E. Bates, S. Grant, R. L. Piekarz, R. W. Johnstone, Y. Dai, B. Lee, M. E. Araujo, H. M. Prince, Epigenomics 2012, 4, 571-589.

[6] a) T. A. Miller, D. J. Witter, S. Belvedere, J. Med. Chem. 2003, 46, $5097-$ 5116 ; b) A. Mai, S. Massa, D. Rotili, I. Cerbara, S. Valente, R. Pezzi, S. Simeoni, R. Ragno, Med. Res. Rev. 2005, 25, 261-309. 
[7] a) A. Mai, S. Massa, R. Ragno, M. Esposito, G. Sbardella, G. Nocca, R. Scatena, F. Jesacher, P. Loidl, G. Brosch, J. Med. Chem. 2002, 45, 1778-1784 b) A. Mai, S. Massa, R. Ragno, I. Cerbara, F. Jesacher, P. Loidl, G. Brosch, J. Med. Chem. 2003, 46, 512-524; c) A. Mai, S. Massa, I. Cerbara, S. Valente R. Ragno, P. Bottoni, R. Scatena, P. Loidl, G. Brosch, J. Med. Chem. 2004, 47, 1098-1109; d) R. Ragno, A. Mai, S. Massa, I. Cerbara, S. Valente, P. Bottoni, R. Scatena, F. Jesacher, P. Loidl, G. Brosch, J. Med. Chem. 2004, 47, 1351 -1359; e) A. Mai, S. Massa, R. Pezzi, S. Simeoni, D. Rotili, A. Nebbioso, A. Scognamiglio, L. Altucci, P. Loidl, G. Brosch, J. Med. Chem. 2005, 48, 3344-3353; f) A. Mai, S. Massa, S. Valente, S. Simeoni, R. Ragno, P. Bottoni, R. Scatena, G. Brosch, ChemMedChem 2006, 1, 225 237; g) A. Mai, S. Valente, D. Rotili, S. Massa, G. Botta, G. Brosch, M Miceli, A. Nebbioso, L. Altucci, Int. J. Biochem. Cell Biol. 2007, 39, 1510 1522; h) A. Mai, S. Valente, A. Nebbioso, S. Simeoni, R. Ragno, S. Massa, G. Brosch, F. De Bellis, F. Manzo, L. Altucci, Int. J. Biochem. Cell Biol. 2009, 41, 235-247; i) S. Valente, M. Conte, M. Tardugno, S. Massa, A. Nebbioso, L. Altucci, A. Mai, ChemMedChem 2009, 4, 1411-1415.

[8] a) A. Mai, S. Massa, R. Pezzi, S. Valente, P. Loidl, G. Brosch, Med. Chem. 2005, 1, 245-254; b) F. Thaler, A. Colombo, A. Mai, R. Amici, C. Bigogno, R. Boggio, A. Cappa, S. Carrara, T. Cataudella, F. Fusar, E. Gianti, S. J. di Ventimiglia, M. Moroni, D. Munari, G. Pain, N. Regalia, L. Sartori, S. Vultaggio, G. Dondio, S. Gagliardi, S. Minucci, C. Mercurio, M. Varasi, J. Med. Chem. 2010, 53, 822-839; c) M. Varasi, F. Thaler, A. Abate, C. Bigogno, R. Boggio, G. Carenzi, T. Cataudella, R. Dal Zuffo, M. C. Fulco, M. G. Rozio, A. Mai, G. Dondio, S. Minucci, C. Mercurio, J. Med. Chem. 2011, 54, 3051-3064; d) S. Valente, M. Tardugno, M. Conte, R. Cirilli, A. Perrone, R. Ragno, S. Simeoni, A. Tramontano, S. Massa, A. Nebbioso, M. Miceli, G. Franci, G. Brosch, L. Altucci, A. Mai, ChemMedChem 2011, 6 698-712; e) M. Meli, M. Tolomeo, M. Grifantini, A. Mai, L. Cappellacci, R. Petrelli, D. Rotili, A. Ferro, P. Saiko, T. Szekeres, L. Dusonchet, Int. J. Oncol. 2011, 38, 1427-1436; f) F. Thaler, M. Varasi, A. Colombo, R. Boggio, D. Munari, N. Regalia, M. G. Rozio, V. Reali, A. E. Resconi, A. Mai, S. Gagliardi, G. Dondio, S. Minucci, C. Mercurio, ChemMedChem 2010, 5 $1359-1372$.

[9] a) A. Mai, S. Massa, D. Rotili, R. Pezzi, P. Bottoni, R. Scatena, J. Meraner, G. Brosch, Bioorg. Med. Chem. Lett. 2005, 15, 4656-4661; b) A. Mai, D. Rotili, S. Massa, G. Brosch, G. Simonetti, C. Passariello, A. T. Palamara, Bioorg. Med. Chem. Lett. 2007, 17, 1221-1225; c) A. Mai, S. Massa, D. Rotili, S. Simeoni, R. Ragno, G. Botta, A. Nebbioso, M. Miceli, L. Altucci, G. Brosch, J. Med. Chem. 2006, 49, 6046-6056; d) A. Mai, K. Jelicic, D. Rotili, A. Di Noia, E. Alfani, S. Valente, L. Altucci, A. Nebbioso, S. Massa, R. Galanello, G. Brosch, A. R. Migliaccio, G. Migliaccio, Mol. Pharmacol. 2007, 72, 1111 -1123; e) A. Mai, A. Perrone, A. Nebbioso, D. Rotili, S. Valente, M. Tardugno, S. Massa, F. De Bellis, L. Altucci, Bioorg. Med. Chem. Lett. 2008, 18, 2530-2535.

[10] a) S. Inoue, A. Mai, M. J. Dyer, G. M. Cohen, Cancer Res. 2006, 66, 67856792 ; b) V. Duong, C. Bret, L. Altucci, A. Mai, C. Duraffourd, J. Loubersac P. O. Harmand, S. Bonnet, S. Valente, T. Maudelonde, V. Cavailles, N. Boulle, Mol. Cancer Res. 2008, 6, 1908-1919; c) A. Scognamiglio, A. Nebbioso, F. Manzo, S. Valente, A. Mai, L. Altucci, Biochim. Biophys. Acto Mol. Cell Res. 2008, 1783, 2030-2038; d) A. Nebbioso, F. Manzo, M Miceli, M. Conte, L. Manente, A. Baldi, A. De Luca, D. Rotili, S. Valente, A. Mai, A. Usiello, H. Gronemeyer, L. Altucci, EMBO Rep. 2009, 10, $776-$ 782; e) B. Illi, C. Dello Russo, C. Colussi, J. Rosati, M. Pallaoro, F. Spallotta, D. Rotili, S. Valente, G. Ragone, F. Martelli, P. Biglioli, C. Steinkuhler, P.
Gallinari, A. Mai, M. C. Capogrossi, C. Gaetano, Circ. Res. 2008, 102, $51-$ 58; f) A. Nebbioso, C. Dell'Aversana, A. Bugge, R. Sarno, S. Valente, D. Rotili, F. Manzo, D. Teti, S. Mandrup, P. Ciana, A. Maggi, A. Mai, H. Gronemeyer, L. Altucci, J. Mol. Endocrinol. 2010, 45, 219-228; g) S. Saito, J. A. Lasky, W. Guo, H. Nguyen, A. Mai, S. Danchuk, D. E. Sullivan, B. Shan, Biochem. Biophys. Res. Commun. 2011, 408, 630-634; h) O. Lenoir, K. Flosseau, F. X. Ma, B. Blondeau, A. Mai, R. Bassel-Duby, P. Ravassard, E. N. Olson, C. Haumaitre, R. Scharfmann, Diabetes 2011, 60, 2861-2871; i) I. Palmisano, G. Della Chiara, R. L. D'Ambrosio, C. Huichalaf, P. Brambilla, S. Corbetta, M. Riba, R. Piccirillo, S. Valente, G. Casari, A. Mai, F. Martinelli Boneschi, D. Gabellini, G. Poli, M. V. Schiaffino, Proc. Natl. Acad. Sci. USA 2012, 109, E2284- 2293.

[11] Y. Itoh, T. Suzuki, A. Kouketsu, N. Suzuki, S. Maeda, M. Yoshida, H. Nakagawa, N. Miyata, J. Med. Chem. 2007, 50, 5425-5438.

[12] A. P. Kozikowski, S. Tapadar, D. N. Luchini, K. H. Kim, D. D. Billadeau, J. Med. Chem. 2008, 51, 4370-4373.

[13] A. Lahm, C. Paolini, M. Pallaoro, M. C. Nardi, P. Jones, P. Neddermann, S. Sambucini, M. J. Bottomley, P. Lo Surdo, A. Carfi, U. Koch, R. De Francesco, C. Steinkuhler, P. Gallinari, Proc. Natl. Acad. Sci. USA 2007, 104, $17335-17340$.

[14] H. Zou, Y. Wu, M. Navre, B. C. Sang, Biochem. Biophys. Res. Commun. 2006, 341, 45-50.

[15] A. Roy, A. Kucukural, Y. Zhang, Nat. Protoc. 2010, 5, 725-738.

[16] K. V. Butler, J. Kalin, C. Brochier, G. Vistoli, B. Langley, A. P. Kozikowski, J. Am. Chem. Soc. 2010, 132, 10842-10846.

[17] H. Hess-Stumpp, T. U. Bracker, D. Henderson, O. Politz, Int. J. Biochem. Cell Biol. 2007, 39, 1388-1405.

[18] A. Nebbioso, N. Clarke, E. Voltz, E. Germain, C. Ambrosino, P. Bontempo, R. Alvarez, E. M. Schiavone, F. Ferrara, F. Bresciani, A. Weisz, A. R. de Lera, H. Gronemeyer, L. Altucci, Nat. Med. 2005, 11, 77-84.

[19] L. Auzzas, A. Larsson, R. Matera, A. Baraldi, B. Deschenes-Simard, G. Giannini, W. Cabri, G. Battistuzzi, G. Gallo, A. Ciacci, L. Vesci, C. Pisano, S. Hanessian, J. Med. Chem. 2010, 53, 8387-8399.

[20] a) Y. Li, D. Shin, S. H. Kwon, FEBS J. 2013, 280, 775-793; b) G. Li, H. Jiang, M. Chang, H. Xie, L. Hu, J. Neurol. Sci. 2011, 304, 1-8.

[21] A. Schuetz, J. Min, A. Allali-Hassani, M. Schapira, M. Shuen, P. Loppnau, R. Mazitschek, N. P. Kwiatkowski, T. A. Lewis, R. L. Maglathin, T. H. McLean, A. Bochkarev, A. N. Plotnikov, M. Vedadi, C. H. Arrowsmith, J. Biol. Chem. 2008, 283, 11355-11363.

[22] E. F. Pettersen, T. D. Goddard, C. C. Huang, G. S. Couch, D. M. Greenblatt, E. C. Meng, T. E. Ferrin, J. Comput. Chem. 2004, 25, 1605-1612.

[23] D. Trisciuoglio, Y. Ragazzoni, A. Pelosi, M. Desideri, S. Carradori, C. Gabellini, G. Maresca, R. Nescatelli, D. Secci, A. Bolasco, B. Bizzarri, C. Cavaliere, I. D’Agnano, P. Filetici, L. Ricci-Vitiani, M. G. Rizzo, D. Del Bufalo, Clin. Cancer Res. 2012, 18, 475-486.

[24] J. E. Bradner, N. West, M. L. Grachan, E. F. Greenberg, S. J. Haggarty, T. Warnow, R. Mazitschek, Nat. Chem. Biol. 2010, 6, 238-243.

[25] L. Altucci, A. Rossin, W. Raffelsberger, A. Reitmair, C. Chomienne, H. Gronemeyer, Nat. Med. 2001, 7, 680-686.

Received: January 3, 2013

Revised: February 16, 2013

Published online on March 25, 2013 